\title{
KARUNIA ROH MENURUT PENGAJARAN RASUL PAULUS: SUATU KAJIAN TEOLOGIS TERHADAP PANDANGAN NEO-PENTAKOSTA TENTANG KARUNIA SPEKTAKULAR
}

\author{
ROBERT CALVIN WAGEY
}

\begin{abstract}
PENDAHULUAN
Karunia Roh Kudus adalah perlengkapan rohani yang Allah anugerahkan kepada setiap orang percaya atau Gereja dengan tujuan untuk digunakan bagi pekerjaan pelayanan dan pembangunan tubuh Kristus (bnd. Ef 4:11,16; 1Kor 12:7). Karunia Roh Kudus sangat bermanfaat di dalam melaksanakan amanat Agung Tuhan Yesus Kristus yang diberikan kepada orang percaya dan Gereja. Keberhasilan Gereja di dalam mewujudkan pelayanan kesaksian, persekutuan dan diakonia tidak dapat dipisahkan dari pemanfaatan karunia-karunia roh yang dianugerahkan Allah kepadanya. Gereja akan bertumbuh secara kualitatif dan kuantitatif apabila seluruh potensi, karunia-karunia roh, yang ada pada setiap anggota digunakan semaksimal mungkin. Karena itulah maksud dan tujuan Allah memberikannya kepada jemaat. Tetapi sangat disayangkan, pada masa kini, potensi yang besar yang Allah anugerahkan kepada jemaat yang seharusnya menjadi berkat bagi sesama anggota jemaat dan perkembangan Gereja, justru menimbulkan masalah.

Beberapa karunia Roh kudus tertentu menimbulkan kontroversi bahkan membingungkan sebagian orang percaya ketika melihat 'keekstriman' tanggapan serta pemanfaatannya. Kenyataan ini dilatar belakangi oleh penafsiran dan pengertian yang berbeda-beda dari beberapa kelompok tertentu tentang hakikat karunia-karunia Roh dan signifikansinya untuk Gereja Tuhan pada masa kini. ${ }^{1}$

Ada pandangan yang cenderung membeda-bedakan bahkan sangat menekankan dan mengutamakan karunia-karunia Roh tertentu, khususnya karunia-karunia Roh yang bersifat spektakular. Pandangan ini nampak dalam Kelompok Neo-Pentakosta. Lebih ekstrim lagi, ada yang menyatakan bahwa karunia-karunia Roh yang diberikan Allah kepada
\end{abstract}

${ }^{1}$ Wayne Grundem (ed.), Are Miraclous Gifts For To day, Four Views (Leicester: InterVarsity Press, 1996), 9-13; bnd. Peter Wagner, Manfaat Karunia-karunia Roh untuk Pertumbuhan Gereja (Malang: Gunung Mas, 1987), 79. 
orang percaya atau jemaat, hanya terbatas sembilan karunia Roh, yang dinyatakan dalam 1Korintus 12:8-10. ${ }^{2}$ Menurut pandangan ini, karuniakarunia Roh tersebut hanya dimiliki oleh orang percaya ketika mereka mengalami baptisan Roh, yang ditandai dengan karunia untuk berkata-kata dengan bahasa roh. Pengalaman baptisan Roh adalah merupakan pengalaman yang berbeda dan tidak sama dengan pekerjaan Roh Kudus di dalam proses kelahiran baru, yang menjadikan seseorang bertobat dan percaya kepada Kristus, untuk menerima keselamatan. ${ }^{3}$

Pemahaman ini berakibat 'fatal' di dalam pneumatologi. Bilamana penerimaan karunia Roh Kudus hanya terbatas pada mereka yang telah mengalami baptisan Roh Kudus, dan pengalaman baptisan Roh Kudus merupakan pengalaman yang berbeda dan terpisah dari pengalaman kelahiran baru dan pertobatan, maka konsekuensi logis adalah tidak semua orang percaya mengalami Baptisan Roh Kudus, dan dengan demikian tidak semua orang percaya memiliki karunia Roh Kudus.

Memperhatikan masalah tersebut, maka penulis terdorong untuk meneliti apa itu hakikat karunia Roh menurut pengajaran rasul Paulus, yang kemudian hal itu dipakai sebagai landasan teori menanggapi permasalahan tersebut.

\section{HAKIKAT KARUNIA-KARUNIA ROH}

Paulus adalah seorang Rasul yang paling banyak berbicara tentang karunia-karunia Roh Kudus dibandingkan dengan Rasul yang lain. Oleh karena itu untuk memahami tentang apa itu karunia Roh Kudus dan bagaimana peranannya di dalam diri orang percaya maka penulis ingin meneliti bagaimana hal itu dikemukakan oleh Rasul Paulus di dalam suratsuratnya, secara khusus di surat Roma, 1Korintus dan Efesus.

2 Bnd. J.L. Ch. Abineno, Karunia-karunia Roh Kudus (Jakarta: BPK Gunung Mulia 1980), 9,12; R. Budiman," Menentukan Sikap Terhadap Gerakan Kharismatik”, Dalam Gerakan Kharismatik Apakah Itu (Jakarta: BPK Gunung Mulia, 1980), 179; Larry Christenson, Speaking in Tongues (Minneapolis: Dimension Books, 1975), 114,117; Howard M. Ervin, These Are No Drunken, as You Suppose (Plainfield, N.J: Logos International, 1968), 216; Kevin And Dorothy Ranagham, Catholic Pentecostals (Paramus, N.J: Paulist Press, 1969), 160; Gordond Fee, Paul, the Spirit, and the People of God (Peabody Massachusetts: Hendrickson Publishers, 2003), 164 165; Wagner, Ibid.

${ }^{3}$ Bnd. Christenson, Speaking in Tangues..., 37. 


\section{Terminologi}

Di dalam pengajaran rasul Paulus, ada beberapa istilah Yunani yang dipergunakan oleh Rasul Paulus, yang mempunyai hubungan dengan pengertian karunia-karunia Roh, yaitu: Pneumatikos, Charisma dan Dorea. $^{4}$

\section{Pneumatikos}

Rasul Paulus, ketika membahas mengenai masalah karunia-karunia Roh yang ada di dalam jemaat Korintus, mempergunakan istilah Pneumatikos sebanyak dua kali dalam bentuk jamak: dalam 1Korintus 12:1 pneumatikon dan 1Korintus 14:1 pneumatika. Lembaga Alkitab Indonesia (LAI) menterjemahkan istilah tersebut dengan kata karunia-karunia Roh. Searah dengan hal itu, King James Version dan Interlinear Greek-English New Testament menerjemahkannya dengan spiritual gifts, dengan catatan samping ataupun dengan gifts dalam cetakan miring, untuk menyatakan bahwa hal tersebut tidak dengan pasti diterjemahkan dari istilah tersebut. Terjemahan yang demikian juga diikuti oleh The New International Version. $^{5}$

Beberapa Teolog memberikan beberapa pendapat mengenai hal itu. Ada yang berpendapat bahwa istilah pneumatikon sebenarnya dipergunakan oleh Paulus khusus untuk berbicara mengenai "karunia untuk berkata-kata dengan bahasa roh." " Yang lain mengemukakan bahwa istilah ini sebenarnya berbicara tentang manusia-manusia rohani bukan hal-hal rohani. ${ }^{7}$ Tetapi ada juga yang menyatakan bahwa istilah pneumatikon mungkin berbicara tentang hal-hal rohani (karunia-karunia rohani) ataupun juga manusia-manusia rohani, sebab tidak mudah untuk membedakan

\footnotetext{
${ }^{4}$ Bnd. J. Strong, Exhaustive Concordance of the Bible (Nashville: Thomas Nelson Publishers, 1979), 385.

${ }^{5}$ Bnd. Kenneth Barker (gen.ed.), The NIV Study Bible (Grand Rapids: Zondervan: 1984), 1750, 1752; Interlinear Greek-English New Testament (Grand Rapids: Baker Book House: 1981), 619, 624; The Iversen-Norman Associates, The Zondervan Parallel New Testament in Greek and English (Grand Rapids: Zondervan, 1979), 508, W. Sihite, Pemberian di dalam Perjanjian Baru, dalam Theo-Doron, Pemberian Allah, M.A. Ihromi, ed. (Jakarta: BPK Gunung Mulia, 1979), 17.

${ }^{6}$ Mereka adalah : Storr, Heydenreich, Baur, Wieseler; dikutip dari H.A.W. Meyer, Meyer's Commentary on the New Testament. Vol. VI (Winona Lake: Alpha Publications, 1980), 275.

${ }^{7}$ Mereka adalah : Grotius Hammond; dikutip dari Henry Alford, Alford's Greek Testament. Vol.I \& II (Chicago: Moody Press, 1958), 576.
} 
antara hal-hal rohani dengan manusia-manusia rohani. manusia-manusia rohani adalah mereka yang memiliki karunia-karunia rohani, antara lain karunia untuk berkata-kata dengan bahasa roh. ${ }^{8}$

Memang istilah pneumatikon, bilamana dilihat dari jenis kelaminnya, dapat dinyatakan sebagai neuter (yang diartikan sebagai 'hal-hal rohani') ataupun juga masculine (yang diartikan sebagai "orang-orang rohani"). ${ }^{9}$ Karena itu, sepintas lalu memang sulit untuk membedakan dan menyatakan dengan pasti apa yang dimaksud dengan istilah tersebut. Untuk dapat memecahkan masalah ini maka perlu diselidiki dan dipahami apa yang dimaksud oleh Rasul Paulus ketika ia mempergunakan istilah tersebut dalam konteks 1Korintus 12.

Dalam 1Korintus 12:1, ada satu istilah Yunani yang dipergunakan oleh rasul Paulus, yaitu istilah de yang sering diterjemahkan now, but, sekarang atau tetapi. LAI menterjemahkan dengan kata sekarang. Istilah ini mempunyai pengertian dan menunjukkan bahwa pokok pembahasan dalam 1Korintus 12 adalah berbeda dan tidak mempunyai hubungan dengan pembahasan sebelumnya. ${ }^{10}$ Sehingga yang menjadi pokok pembahasannya adalah apa yang diuraikan dalam pasal tersebut. Dalam I Kor 12:4-11, yang menjadi pokok pembahasan rasul Paulus adalah mengenai karunia-karunia Roh yang diberikan oleh Allah kepada jemaat Korintus. Sehingga penekanan dalam pembahasan rasul Paulus adalah mengenai karuniakarunia tersebut dan bukan kepada manusia yang menerima karuniakarunia tersebut.

Hal ini lebih jelas nampak dalam istilah Yunani charismata yang dipergunakan Paulus dalam ayat 4, yang menunjuk kepada pengertian tersebut, yaitu rupa-rupa karunia (penguraian lebih luas dari istilah ini akan dibahas dalam butir kedua). Sebagaimana yang dikatakan oleh Lenski : "In $v .4$ they are called 'charismata' in the technical sense of this term, namely special gifts of the Spirit that were portioned out to different individuals." 11

Dalam ayat 28-29, memang dibicarakan juga mengenai mereka yang menerima karunia-karunia.:" Dan Allah telah menetapkan beberapa orang dalam Jemaat: Pertama sebagai rasul, kedua sebagai nabi, ketiga

8 Bnd. C.K. Barrett, A Commentary on the First Epistle to the Corinthians (London: Adam \& Charles Black, 1979), 278.

9 Bnd. Arndt \& Gingrich, A Greek English Lexicon of the New Testament (Chicago: The University of Chicago Press, 1971), 685.

${ }^{10}$ Bnd. J.H. Thayer, Thayer's Greek English Lexicon of the New Testament (Grand Rapids: Baker Book House, 1981), 125.

${ }^{11}$ R.C.H. Lenski, The Interpretation of St. Paul's First and second Epistle to Corinthians ( Minneopolis: Augburg Publishing House, 1963), 490. 
sebagai pengajar. Selanjutnya mereka yang mendapat karunia... Adakah mereka semua rasul, atau nabi atau pengajar? Adakah mereka semua mendapat karunia..." Tetapi penekanan yang sebenarnya bukan pada mereka yang menerima karunia-karunia, tetapi pada sumber dari karuniakarunia Roh. Hal tersebut nampak dalam ayat 28a: "Dan Allah telah menetapkan beberapa orang dalam Jemaat."

Dengan demikian, yang menjadi penekanan pembahasan Paulus dalam 1Korintus 12 adalah pada karunia-karunia Roh yang telah diberikan Allah kepada jemaat Korintus dan sekaligus menunjukkan kepada sumber dari karunia-karunia tersebut. Tujuannya untuk menyadarkan jemaat Korintus yang terlalu membanggakan karunia-karunia tertentu, yang bersifat spektakular dan meremehkan yang non spektakular, bahwa semua karunia tersebut tanpa terkecuali adalah sama dalam kualitasnya karena dari Allah yang satu yang menganugerahkannya kepada mereka, yang berbeda adalah pada manifestasinya dan fungsinya. Tentu saja dalam membicarakan karunia-karunia tersebut, Paulus akan menyinggung mengenai mereka (manusia-manusia rohani) yang memilikinya, dengan tujuan agar mereka saling menghargai juga akan karunia Roh yang telah Allah anugerahkan kepada mereka masing-masing. Sebab semuanya itu diberikan Allah untuk kepentingan mereka bersama bagi pertumbuhan dan pengembangan jemaat sebagai tubuh Kristus.

Hal itu berarti bahwa yang dimaksud dengan istilah pneumatikon bukan khusus tertuju kepada manusia-manusia rohani ataupun khusus mengenai "karunia untuk berkata-kata dengan bahasa roh" melainkan berbicara khusus mengenai seluruh karunia Roh yang beraneka ragam dan multi fungsi yang telah diberikan oleh Allah kepada jemaat Korintus. ${ }^{12}$

Pengertian ini juga sama dengan pengertian dari istilah pneumatika dalam 1Korintus 14:1. ${ }^{13}$ Tujuan rasul Paulus mempergunakan istilah pneumatikon atau pneumatika bagi karunia-karunia Roh yang ada dalam jemaat Korintus, nampak dalam penguraian selanjutnya ini.

Istilah pneumatikon atau pneumatika (bentuk tunggalnya pneumatikos) berasal dari kata pneuma, yang mempunyai banyak pengertian, antara lain roh. Dalam Perjanjian Baru khususnya dalam pengajaran rasul Paulus, istilah pneuma sering dipergunakan untuk menyatakan tentang Roh Kudus. Sedangkan arti pneumatikos adalah sesuatu yang berasal Roh Kudus dan menjadi milik Roh Kudus. ${ }^{14}$ Sehingga

12 Bnd. H. Ridderbos, Paul: An Outline of His Theology (Grand Rapids: Eerdmans, 1977), 442.

${ }^{13}$ Bnd. Meyer, Meyer's Commentary On The New..., 315.

${ }^{14}$ Bnd. Thayer, Thayer's Greek English Lexicon..., 521-523. 
istilah pneumatikon atau pneumatika menunjukkan bahwa karunia-karunia adalah berasal dari Roh dan menjadi milik Roh Kudus. Kemungkinan dalam pengertian ini sehingga King James Version dan Alkitab bahasa Inggris yang lain menterjemahkan istilah pneumatikon atau pneumatika dengan spiritual gifts atau oleh LAI diterjemahkan karunia-karunia Roh. Jadi hal ini merupakan suatu penafsiran.

Hal itu menunjukkan bahwa Paulus mempergunakan istilah pneumatikon atau pneumatika untuk segala karunia yang ada di dalam jemaat Korintus adalah untuk menyatakan bahwa karunia-karunia tersebut bersifat dan mempunyai tujuan rohani, bukan duniawi. Karena hal tersebut bukan berasal dari diri manusia sendiri, melainkan dari Roh Kudus dan digerakkan oleh Roh Kudus, suatu manifestasi dari Roh Kudus. ${ }^{15}$ Karuniakarunia Roh adalah suatu kesanggupan khusus yang diberikan oleh Allah kepada setiap orang percaya untuk melayani pekerjaan-Nya dan demi untuk kemuliaan nama-Nya. ${ }^{16}$ Ia akan memampukan setiap orang percaya untuk melayani secara efektif dalam ladang pelayanan yang Allah percayakan kepada mereka masing-masing sehingga tujuan dan sasaran yang ingin dicapai oleh Allah di dalam jemaat dan dunia terwujud dengan baik.

\section{Charisma}

Dalam Perjanjian Baru, selain 1Petrus 4:10, istilah Charisma adalah merupakan suatu istilah yang hanya dipergunakan oleh rasul Paulus. ${ }^{17}$ Searah dengan hal tersebut nampak dalam pernyataan Richard B. Gaffin, bahwa "Paul is apparently the first to make it an important (theological) term."18 Istilah charisma (bentuk jamak charismata) berarti suatu hadiah atau pemberian cuma-cuma yang diberikan berdasarkan anugerah atau kasih karunia Allah. ${ }^{19}$ Dengan demikian, charisma bukanlah suatu pemberian yang diterima oleh seseorang berdasarkan jasa baik atau hasil

15 Bnd. Donald Bridge \& David Phyphers, Karunia-karunia Roh dan Jemaat (Bandung: Kalam Hidup, 1973), 20.

${ }^{16}$ Bnd. 1Korintus 12:3c.

${ }^{17}$ Bnd. G. Kittel, Theological Dictionary of the New Testament. Vol. IX (Grand Rapids: Eerdmans, 1978), 403.

${ }^{18}$ Richard B. Gaffin, Jr., Perspective on Pentecost, New Testament Teaching on the gifts of the Holy Spirit (New Jersey: Presbyterian and Reformed Publishing Company, 1979), 46.

${ }^{19}$ W.E. Vine, An Expository Dictionary Of New Testament Words (New Jersey: Fleming H Revell Company, 1966), 147. 
perbuatannya sendiri tetapi semata-mata berdasarkan belaskasihan Allah. ${ }^{20}$ Istilah ini berasal dari istilah charizomai, yang juga mempunyai hubungan dengan istilah charis yang berarti "anugerah atau kasih karunia."15

Dalam pengajaran rasul Paulus, kedua istilah charisma dan charis sering dipergunakan dalam pengertian yang sama dan hampir tidak ada perbedaan. Sehingga kedua istilah ini saling tumpang tindih dan kait mengait. Misalnya dalam Efesus 4:7 istilah charis dipergunakan untuk kasih karunia yang dianugerahkan kepada jemaat menurut ukuran pemberian Kristus. Dalam ayat ini, istilah charis dipergunakan dalam pengertian dari istilah charisma. ${ }^{16}$ Sebaliknya, dalam Roma 5:15-21, istilah charisma dipakai untuk kasih karunia Allah yang dinyatakan di dalam Kristus bagi keselamatan manusia. Hal yang sama digunakan dalam Roma 6:23. Dalam ayat-ayat tersebut, istilah ini dipakai dalam pengertian dari istilah charis. ${ }^{17}$ Dalam Roma 11:29, istilah charisma dipakai dalam bentuk jamak charismata, untuk kasih karunia Allah dalam memilih dan menjadikan bangsa Israel sebagai umat kesayangan-Nya. Maksud Paulus mempergunakan istilah charisma atau charismata dalam ayat-ayat tersebut, adalah untuk menyatakan tentang sifat dan hakekat keselamatan yang diberikan Allah kepada manusia dan pemilihan-Nya bagi bangsa Israel sebagai umat kesayangan-Nya. Yaitu, bahwa semua hal tersebut adalah semata-mata didasarkan atas kasih dan anugerah Allah, bukan karena perbuatan dan kebaikan bangsa Israel. ${ }^{18}$

Selain dipergunakan dalam pengertian hal tersebut di atas, istilah charisma ini dipergunakan secara khusus oleh Paulus untuk karuniakarunia Roh yang ada dalam jemaat, dalam kaitan dengan pelayanan jemaat (bnd. Rm 12:6, 1Kor 1:7, 7:7, 12:4,9,28,30,31; 1Tim 4:14; 2Tim 1:6).

Istilah ini sering dipergunakan dalam bentuk jamak charismata atau charismaton. Yaitu, dalam Roma 12:6 dipergunakan untuk semua karunia yang ada dalam jemaat Roma, yang disebutkan dalam Roma 12:6-8. Dalam 1Korintus. 12:4, berkaitan dengan kesembilan karunia yang disebutkan dalam 1Korintus 12:8-10.

${ }^{20}$ Bnd. James Orr, The International Standard Bible Encyclopedia. Vol. IV (Grand Rapids: Eerdmans, 1960), 1228.

${ }^{15}$ Strong, Exhaustive Concordance of the Bible, dalam Greek Dictionary of the New Testament..., 177.

16 Bnd. Colin Brown, The New International Dictionary of New Testament Theology. Vol.III (Grand Rapids: Zondervan, 1979), 120.

${ }^{17}$ Ibid.

${ }^{18}$ Bnd. Duane A. Priebe, Charismatic Gifts and Christian Existence in Paul, dikutip dari J.E. Grimson, Gifts of the Spirit and the Body of Christ (Minneopolis: Augsburg Publishing House, 1974), 20. 
Dalam 1 Korintus 12:31, istilah ini dipergunakan untuk karuniakarunia yang paling utama; dan dalam 1 Korintus 12:9,28,30, istilah ini dipergunakan untuk karunia-karunia penyembuhan.

Dalam 1 Korintus 7:7, hidup melajang seperti rasul Paulus, demi untuk melayani Tuhan tanpa gangguan, ${ }^{19}$ dikategorikan sebagai salah satu charisma dari karunia-karunia Roh di dalam jemaat. ${ }^{20}$ Demikian juga dalam 1 Timontius 4:14, 2 Timotius 1:6, jabatan Timotius sebagai pejabat Gereja dalam menggembalakan dan memimpin jemaat Efesus adalah suatu charisma, sesuai dengan nubuatan dan penumpangan tangan para penatua.

Kenyataan tersebut di atas menunjukkan bahwa karunia-karunia Roh adalah berbagai macam ragam dan tidak hanya terbatas dalam jenis karunia tertentu. Karunia atau charisma itu bukan hanya berkaitan dengan berbagai ragam karunia yang luar biasa atau karunia yang bersifat spektakular, seperti: karunia penyembuhan, membuat mujizat, berbahasa roh atau bernubuat tetapi juga berkaitan dengan segala karunia yang bersifat natural yang bermanfaat bagi pembangunan jemaat. ${ }^{21}$ Walaupun mungkin hal itu kelihatan tidak ada artinya dan tidak bernilai karena tidak begitu menonjol, seperti yang dikatakan oleh Abraham Kuyper: "Every means afforded by the King for the doing of His work is a charisma, a gifts of grace." ${ }^{22}$ Sebab itu, karunia-karunia Roh Kudus tidak bisa dikotakkotakkan dan dibedakan secara kualitatif. Tidak boleh dibedakan antara karunia yang kelihatan spektakular dan natural. ${ }^{23}$ Sebab konsepsi yang demikian tak ada dalam istilah charisma. Rasul Paulus dalam pengajarannya tentang segala macam karunia Roh Kudus tak pernah membedakan atau mengistimewakan karunia tertentu. Hal ini nyata dalam uraiannya di 1 Korintus 12. Ia dengan tegas menasehati para pemilik karunia yang bersifat spektakular untuk menghargai sesama orang percaya yang memiliki karunia yang kelihatannya non spektakular karena hal itu juga berasal dari Allah.

Dari semua uraian tersebut di atas menunjukkan bahwa istilah charisma mempunyai banyak pengertian. Hal itu tidak hanya khusus dipergunakan untuk karunia-karunia yang diberikan kepada jemaat dalam

${ }^{19}$ Bnd. 1Kor 7:34a, 35b.

${ }^{20}$ Bnd. Peter Wagner, Your Spiritual gifts can help your Church Grow (Glendale: G.L. Regal Books, 1980), 65.

${ }^{21}$ Bnd. Hadiwijono, Iman Kristen (Jakarta: BPK Gunung Mulia, 1979), 315. 1975), 184.

22 Abraham Kuyper, The Work Of The Holy Spirit (Grand Rapids: Eerdmans,

${ }^{23}$ Bnd. George A. Buttrick, The Interpreter's Dictionary of the Bible. Vol. IV (Nashville: Abingdon Press, 1978), 435. 
kaitan dengan pelayanan jemaat melainkan juga dipergunakan untuk semua charis Allah yang telah dinyatakan dalam karya keselamatan Kristus bagi manusia melalui Roh Kudus. ${ }^{24}$ Sebab itu, sebagaimana yang telah dikemukakan sebelumnya, bahwa charisma dan charis saling berhubungan satu dengan yang lain. Hal ini memberikan suatu pengertian bahwa Paulus mempergunakan istilah charisma untuk semua karunia Roh yang ada dalam jemaat, adalah untuk menyatakan bahwa semua karunia tersebut, yang bersifat spektakular maupun natural adalah semata-mata pemberian Allah yang diberikan kepada jemaat atas dasar kasih dan anugerah-Nya. Hal itu bukan karena usaha manusia ataupun sebagai pahala atas jasa baik manusia. Karena semua karunia itu adalah pemberian Allah di dalam kedaulatan-Nya dan bersumber dari Allah maka semua karunia Roh Kudus, yang bersifat spektakular maupun yang bersifat natural, adalah sama nilainya dan kualitasnya, tidak ada perbedaan. Yang berbeda adalah fungsinya, cara kerjanya dan penampakkannya di hadapan manusia, ada yang bersifat spektakular dan menakjubkan ada yang kelihatan non-spektakular/natural.

\section{Dorea}

Selain kedua istilah yang telah diuraikan di atas, rasul Paulus juga mempergunakan istilah dorea untuk karunia-karunia, ketika membicarakannya di dalam jemaat (Ef 3:7, 4:7). Istilah ini berasal dari kata doron, yang berarti suatu pemberian atau hadiah ataupun juga suatu pemberian yang sah. Dan dalam Perjanjian Baru, istilah ini digunakan khusus untuk pemberian dari Allah atau Kristus kepada manusia. ${ }^{25}$

Dalam Efesus 3:7, Paulus menyatakan bahwa jabatan dan tugasnya sebagai pelayan Injil adalah merupakan pemberian (dorean) kasih karunia Allah. Hal itu dinyatakannya untuk menekankan bahwa jabatan dan tugasnya tersebut bukan berasal dari manusia maupun dari keinginan dirinya sendiri, melainkan semata-mata dari Allah yang didasarkan atas anugerah-Nya. Alasan ini nampak dalam ayat 8-12 yang menyatakan bahwa kepada Paulus, yang paling hina di antara segala orang kudus, telah dianugerahkan kasih karunia tersebut, untuk memberitakan kepada orangorang bukan Yahudi kekayaan Kristus supaya oleh jemaat diberitahukan pelbagai ragam hikmat Allah kepada pemerintah-pemerintah dan penguasa-

${ }^{24}$ Bnd. Kurt Koch, Charismatic Gifts (Gran Rapids: The Association for Christian Evangelism, 1975), 81.

${ }^{25}$ G. Kittel, Theological Dictionary of the New Testament. Vol. II (Grand Rapids: Eerdmans, 1978), 167. 
penguasa di sorga, sesuai dengan maksud abadi yang dilaksanakan-Nya dalam Kristus Yesus. Selanjutnya, dalam 1Korintus 9:16, Paulus menyatakan bahwa tugas dan jabatan tersebut harus dilaksanakan dengan penuh tanggung jawab dan tanpa pamrih, apapun resiko yang akan dihadapinya. Sebab itulah hakikat daripada karunia, yang telah Allah percayakan kepada setiap hamba-Nya. ${ }^{26}$ Sehingga dalam 1Korintus 9:16 Paulus menyatakan bahwa "Celakalah aku jika aku tidak memberitakan Injil." Searah dengan hal itu juga dikatakan oleh Billy Graham: If I had the gift of evangelism and failed to use it, it would be a sin for me. ${ }^{27}$

Istilah yang sama dipergunakan Paulus dalam Efesus 4:7, ketika dinyatakan bahwa setiap orang percaya telah dianugerahkan kasih karunia menurut ukuran pemberian (doreas) Kristus. Maksudnya, bahwa setiap orang percaya telah diberikan karunia-karunia Roh, menurut ukuran pemberian (doreas) Kristus.

Dalam ayat 8-10 dinyatakan bahwa pemberian itu berkaitan dengan karya keselamatan Kristus bagi manusia, yaitu melalui kematian, kebangkitan dan kenaikan-Nya. Di mana Kristus, yang kepadaNya telah diberikan segala kuasa di surga dan di bumi oleh Allah Bapa, memberikan pemberian-pemberian (domata) kepada jemaat-Nya. ${ }^{28}$ Penggunaan istilah dorea dalam Efesus 4:7 adalah untuk menyatakan bahwa adanya segala karunia Roh di dalam jemaat, dimungkinkan karena karya keselamatan Kristus. Karunia-karunia Roh berasal dari Kristus dan Kristus sendirilah yang menentukan pemberian karunia-karunia tersebut. Sehingga tepat apa yang telah dikatakan oleh D. Martyn Lloyd Jones: "The Lord Jesus Christ is the Head of Church ... is the Giver and Dispenser of all the Gifts." ${ }^{29}$ Tujuan pemberian karunia-karunia itu, dalam kaitan dengan karya keselamatan Kristus bagi jemaat, adalah untuk memperlengkapi jemaat bagi pekerjaan pelayanan dan pembangunan jemaat, sebagai tubuh Kristus (Ef 4:11-16).

Semua hal ini menunjukkan bahwa penggunaan istilah dorea dalam kaitan dengan karunia-karunia Roh, adalah untuk menyatakan bahwa karunia karunia Roh adalah merupakan pemberian atau hadiah yang resmi dari Allah Bapa dan Tuhan Yesus Kristus melalui Roh Kudus, kepada setiap orang percaya. Itu dimungkinkan karena karya keselamatan Kristus di atas kayu salib dan kemenangan-Nya yang terwujud dalam kebangkitan

${ }^{26}$ J.L. Abineno, Tafsiran Surat Efesus (Jakarta: BPK Gunung Mulia, 1977), 99

${ }^{27}$ Billy Graham, The Holy Spirit (New York: Warner Books, 1980), 169.

${ }^{28}$ Bnd. R.C.H. Lenski, The Interpretation of St. Paul's Epistle to the Galatians, the Ephesians, and to the Philippians (Minneapolis: Augsburg Publishing, 1961), 520.

${ }^{29}$ D. Martyn Lloyd Jones, Christian Unity, An Exposition of Ephesians 4:1-16 (Grand Rapids: Baker Book House, 1980), 148. 
dan kenaikkan-Nya ke surga. Karunia-karunia Roh ini dibagi-bagikan menurut kehendak-Nya. Tujuan pemberian karunia-karunia tersebut adalah bagi pelayanan dan pembangunan jemaat, sebagai tubuh Kristus. Karena itu, setiap orang percaya harus mempergunakan segala karunia yang ada padanya dengan penuh tanggung jawab, apapun konsekuensinya.

Dari pembahasan ketiga istilah tersebut di atas dapat ditarik kesimpulan: 1) Menurut Paulus karunia Roh adalah suatu perlengkapan atau kesanggupan khusus, yang diberikan Roh Kudus kepada setiap orang percaya ketika percaya kepada Kristus; 2) Pemberian karunia-karunia tersebut adalah menurut kasih karunia Allah yang didasarkan atas karya keselamatan Kristus. Itu bukan hasil karya dan usaha manusia atau sebagai suatu pahala atas jasa baik manusia. Itu diberi kepada setiap orang secara khusus, seperti yang dikendaki-Nya; 3) Tujuan pemberian karunia-karunia Roh adalah agar setiap orang percaya dimampukan untuk berfungsi secara efektif dalam segala kegiatan pelayanan dan pembangunan jemaat, sebagai tubuh Kristus. Dengan sasaran akhir agar setiap orang percaya mencapai kesatuan iman dan pengetahuan yang benar tentang Anak Allah, kedewasaan penuh, dan tingkat pertumbuhan yang sesuai dengan kepenuhan Kristus. Dengan perkataan lain adalah agar setiap orang percaya berkarakter dan berintegritas serta menampakkan diri sebagai anak Allah yang serupa dan segambar Kristus; 4) Karena itu, semua orang percaya tanpa terkecuali mempunyai tanggung jawab untuk mempergunakan karunianya bagi kepentingan jemaat dan untuk kemuliaan Allah.

\section{Karunia Roh dan Talenta atau Bakat}

Pada dasarnya karunia Roh tidak sama dengan talenta atau bakat. Hal ini nampak dalam pengertian talenta atau bakat itu sendiri. Menurut Webster's New Collegiate Dictionary bahwa talenta adalah suatu kesanggupan atau kecakapan yang khusus dan luar biasa yang dimiliki oleh seseorang secara alami dan telah diwarisi sejak lahir. ${ }^{30}$ Talenta ini nyata pada setiap orang dan mulai nampak pada masa kanak-kanak dan berkembang terus dalam sepanjang kehidupan orang tersebut. Misalnya kesanggupan untuk memainkan salah satu atau bermacam-macam alat musik dengan begitu baik dan melebihi standart kemampuan orang lain. Pengertian ini menunjukkan adanya perbedaan antara karunia dan talenta. Talenta atau bakat adalah bersifat alami sedangkan karunia bersifat rohani. 1973), 485.

${ }^{30}$ H.B. Woolf, Webster' New Collegiate Dictionary (Quezon: Phoenix Press Inc, 
Sebagaimana telah diuraikan sebelumnya bahwa karunia Roh Kudus adalah suatu kesanggupan rohani, yang didasarkan pada kekuatan kuasa Allah atau sebagai suatu manifestasi dari Roh Kudus dan bukan pada diri dan kekuatan manusia secara alami. Oleh karena itu, karunia Roh Kudus mempunyai tujuan rohani, yaitu untuk kepentingan pelayanan dan pembangunan jemaat sebagai tubuh Kristus. Karunia diberikan dan dipergunakan untuk kemuliaan Tuhan.

Sebagaimana karunia-karunia Roh Kudus, talenta juga adalah pemberian Allah kepada manusia, di dalam anugerah-Nya yang umum. Karena itu talenta dimiliki oleh manusia tanpa harus percaya kepada-Nya. ${ }^{31}$ Sebaliknya, karunia Roh Kudus diberikan berdasarkan kasih karunia-Nya kepada setiap orang ketika mereka percaya kepada-Nya.

Sebab itu talenta dipergunakan hanya berkaitan dengan kepentingan kehidupan manusia secara umum tanpa ada hubungan dengan ketaatan kepada Allah dan demi kemuliaan-Nya. Sebagaimana yang dikatakan oleh Ray C. Stedman : “...Talents .. are gifts on a physical or social level only, given to benefit mankind in its 'natural' life. Spiritual gifts, on the other hand, are given for benefit in the realm of the spirit, the realm of individual's relationship to God." 32

Pemakaian istilah charisma yang saat ini sering dipergunakan untuk beberapa tokoh masyarakat, misalnya: Bung Karno ataupun Anwar Sadat, sebenarnya tidak sama pengertiannya dengan charisma atau karunia Roh yang dipergunakan oleh rasul Paulus. Pada dasarnya pengertian charisma untuk tokoh masyarakat adalah talenta atau bakat atau kemampuan manusia secara alamiah bukan charisma dalam pengertian karunia Roh kudus. Sebab pemakaian istilah charisma, sebagaimana telah diuraikan sebelumnya, ${ }^{33}$ selain dalam 1Petrus 4:10 dan sekali dalam surat Philo, hal itu dipergunakan hanya oleh rasul Paulus untuk segala macam karunia Allah yang diberikan dan dikaruniakan-Nya kepada jemaat-Nya, sebagai tubuh Kristus.

Pada abad ke 19 istilah charisma, dalam pengertian bakat atau talenta, mulai dipergunakan dan dipopulerkan oleh seorang sarjana sosiologi terkenal dari Jerman yang bernama Max Weber, bagi setiap pemimpin masyarakat yang berbakat dan menonjol keistimewaan bakatnya dibandingkan dengan setiap anggota masyarakat pada umumnya. ${ }^{34}$

\footnotetext{
${ }^{31}$ Bnd. Wagner, Your Spiritual Gifts Can Help..., 86.

${ }^{32}$ Ray C. Stedman, Body Life (California: Regal Book Division, 1973), 54.

${ }^{33}$ Bnd. uraian tentang pengertian istilah charisma.

${ }^{34}$ Bnd. Wagner, Your Spiritual Gifts..., 86.
} 
Tidak dapat dipungkiri bahwa pada satu segi talenta atau bakat berbeda dengan karunia Roh Kudus, tetapi di lain segi pada tingkat dan peristiwa tertentu keduanya memiliki hubungan satu dengan yang lain. Setiap talenta dari setiap orang dapat diubah oleh Allah menjadi karunia, ketika orang tersebut percaya kepada-Nya. Misalnya, kemampuan mengajar Paulus yang di dapat dari hasil pendidikannya melalui guru besar Gameliel mempunyai hubungan erat dengan karunia mengajar dalam pelayanannya kemudian hari. Demikian juga semua pengalaman hidup Paulus selama di kota Tarsus yang mempunyai penduduk yang multi nasional dan kebudayaan hellenistis, mempunyai hubungan erat dengan karunia rasuli yang ia terima kemudian. ${ }^{35}$ Sehingga ada banyak pendapat, antara lain seperti yang dikemukakan oleh Peter Wagner, bahwa setiap karunia Roh Kudus yang diberikan Allah kepada orang percaya hampir senantiasa searah dengan talenta yang dimilikinya. ${ }^{36}$ Walaupun demikian hal itu tidak senantiasa harus terjadi dan berlangsung seperti itu. D. Scheunemann menyatakan sebagai berikut:

Salah satu hal yang mengherankan dalam kegerakan kebangunan rohani di Timor orang-orang buta huruf yang melalui perlengkapan dari Roh Kudus menjadi pemberita Firman Tuhan yang penuh kuasa, yang meletakkan tangan mereka atas orang sakit dan dalam nama Yesus menyembuhkan mereka, yang dengan nama Yesus juga melepaskan orang dari ikatan okultisme; dan mengusir roh-roh jahat, serta memimpin orang-orang percaya masuk dalam kemerdekaan anak-anak Tuhan. Petani-petani yang sederhana itu menghafal ayatayat Alkitab yang sering mereka terima secara langsung dari Tuhan. Kemudian mereka memberitakan Injil melalui ayat-ayat itu .... ${ }^{37}$

Dengan demikian, karunia-karunia yang diberikan kepada orang percaya sewaktu-waktu searah dengan talenta yang dimiliki, tetapi sewaktuwaktu tidak. Ia bisa diberikan Allah kepada mereka yang sama sekali tidak bertalenta sebagaimana kesaksian tersebut diatas.

Satu hal yang perlu disadari bahwa menerima karunia Roh Kudus dari Tuhan, tidak berarti menghilangkan tanggung jawab untuk memperlengkapi diri dengan pengetahuan umum maupun pengetahuan tentang kebenaran Firman Tuhan. Sebab Tuhan tidak pernah bermaksud agar orang percaya hidup seperti robot tanpa bertanggung jawab mengembangkan potensi yang sudah ia miliki. Oleh karena itu, menerima

\footnotetext{
${ }^{35}$ D. Scheunemann, Sungai Air Hidup (Batu: YPPII, 1979), 87.

${ }^{36}$ Leelie B. Flynn, 19 Gifts of the Spirit (Wheaton: Victor Books, 1980), 23.

${ }^{37}$ Scheunemann, Ibid., 87.
} 
karunia-karunia seperti mengajar, memberitakan Injil ataupun menggembalakan jemaat, tidak berarti menghilangkan kemungkinan untuk belajar atau dipersiapkan dalam pendidikan teologi. Rasul-rasul di Yerusalem yang merupakan dasar berdirinya Gereja mula-mula yang penuh dengan segala hikmat dan pengetahuan, masih membutuhkan pengertian dari rasul Paulus tentang tidak perlunya jemaat yang non Yahudi untuk disunat dan melaksanakan berbagai peraturan hukum Torat (bnd. Kis 15:1 21; Gal 2:1-9).

Sebaliknya, Rasul Paulus belajar dari rasul-rasul di Yerusalem tentang pentingnya pelayanan kepada orang-orang miskin (bnd. Gal 2:10). Jemaat di Korintus yang tidak kekurangan satu karunia Roh, masih perlu dibimbing oleh Paulus untuk hidup menurut kebenaran Firman Tuhan (bnd. 1Kor). Demikian juga Apolos, seorang yang fasih berbicara dan sangat mahir dalam soal-soal Kitab Suci masih membutuhkan bimbingan dan pengetahuan dari Priskila dan Akwila (bnd. Kis 18:24-26). ${ }^{38}$

Dengan demikian, menerima karunia Roh Kudus dari Tuhan tidak berarti telah menjadi sempurna dalam segala hal, khususnya dalam kaitan dengan karunia itu sendiri.

\section{Karunia Roh dan Panggilan Tuhan}

Dalam Efesus 2:10, rasul Paulus menyatakan bahwa setiap orang percaya yang diciptakan di dalam Kristus, mempunyai suatu tujuan yaitu untuk melakukan pekerjaan baik yang dipersiapkan oleh Allah sebelumnya. Berarti setiap orang percaya dipanggil oleh Allah tidak hanya untuk menerima keselamatan dan hidup dalam persekutuan dengan-Nya. Percaya dan masuk dalam persekutuan dengan Allah berarti ikut serta terlibat aktif dalam karya penyelamatan Allah atau Missio Dei bagi dunia ini. Jadi setiap orang percaya harus berfungsi dan berperan aktif di dalam segala kegiatan pelayanan jemaat. Untuk dapat melaksanakan fungsi tersebut, setiap orang percaya diberikan atau diperlengkapi dengan karunia-karunia Roh Kudus minimal satu karunia, sesuai dengan kehendak Tuhan (bnd. Rm 12:3-6; 1Kor 12:7,11; Ef 4:7,16).

Searah dengan hal ini, Peter Wagner menyatakan bahwa "Allah tidak memberi karunia-karunia lalu tidak 'memanggil' si penerima untuk menggunakannya; demikian juga Ia tidak memanggil orang untuk

${ }^{38}$ Scheunemann, Sungai Air..., 87. 
melakukan sesuatu tanpa memperlengkapi orang itu dengan karunia atau karunia-karunia yang perlu untuk melakukan tugas itu." 39

Karunia-karunia tersebut diberikan bukan untuk dipergunakan bagi kepentingan diri sendiri. Karunia-karunia Roh Kudus tidak direncanakan untuk orang-orang yang suka bekerja sendirian. ${ }^{40}$ Demikian juga, karuniakarunia itu diberikan bukan supaya terjadi persaingan dan pertentangan rohani di antara setiap orang percaya (bnd. 1Kor 1:12; 12:14-21). Ia tidak diberikan untuk mengagungkan karunia tertentu di atas karunia-karunia yang lain. Allah tidak pernah merancangkan karunia tertentu menjadi suatu kebesaran rohaniah di beberapa kelompok tertentu dan menjadikan mereka tingkatan kelas yang berbeda, kelas elite rohani, kemudian meremehkan kelompok lain dalam jemaat seperti yang terjadi di dalam jemaat Korintus. Karunia Roh Kudus diberikan Allah untuk dipergunakan bagi kepentingan jemaat bersama dan untuk kemuliaan Allah. Setiap orang percaya mempunyai tanggung jawab atas panggilan pelayanan yang telah diberikan oleh Kristus kepada jemaat. Setiap orang percaya adalah pelayan-pelayan Allah, tidak ada yang bukan pelayan Tuhan, karena semuanya telah dipanggil dan mendapat bagian di dalam diakonat Kristus. ${ }^{41}$ Mereka dipanggil untuk bertumbuh bersama, melayani sesama dan saling berbagi kasih diantara sesama karena mereka adalah umat Allah, anggota keluarga Allah dan warga Kerajaan Allah, yang dipanggil untuk menjadi terang bagi sesama.

Selanjutnya, menurut rasul Paulus bahwa setiap orang percaya mempunyai panggilan dan karunianya yang berbeda-beda. Tiap-tiap orang mendapat suatu tugas pelayanan tersebut. Karena itu juga maka masingmasing orang percaya mempunyai tanggung jawab yang berbeda-beda (bnd. Rm 12:3-8; 1Kor 7:7, 12:29-30). Karena tanggung jawab berbedabeda, maka tidaklah benar bilamana ada orang percaya yang melepaskan tanggung jawabnya dalam pelayanan ataupun mewakilkan pelayanannya serta karunia-karunia yang ada pada mereka kepada saudaranya seiman yang lain. ${ }^{42} \mathrm{Hal}$ itu adalah mustahil.

Demikian juga, tidaklah benar berdalih bahwa mereka hanya memiliki karunia tertentu dan berkosentrasi pada pelayanan tertentu sehingga tidak mau melakukan tugas dan tanggung jawab lainnya, yang

${ }^{39}$ Peter Wagner, Manfaat Karunia Roh Untuk Pertumbuhan Gereja (Malang: Gandum Mas, 1987), 40.

${ }^{40}$ Ibid., 42.

${ }^{41}$ Bnd. J.L.Ch. Abineno, Djemaat (Jakarta: BPK Gunung Mulia, 1965), 100.

${ }^{42}$ Bnd. J.L.Ch. Abineno, Sekitar Theologia Praktika. I (Jakarta: BPK Gunung Mulia, 1979), 102. 
dipercayakan kepadanya. Kepercayaan tersebut harus dihargai dan diwujudkan dengan keyakinan akan pertolongan Tuhan dan kemungkinan pemberian perlengkapan tambahan dari Allah sesuai dengan kebutuhannya.

Walaupun demikian, setiap orang percaya tidak dapat dipaksakan untuk melakukan tugas dan tanggung jawab dari saudaranya seiman atau setiap orang percaya tidak harus memaksakan dirinya untuk melakukan tugas dan tanggung jawab yang bukan menjadi panggilannya. ${ }^{43} \mathrm{Hal}$ itu tidak akan terlaksanakan secara efektif bahkan mungkin dapat mengganggu kelancaran jalannya pelayanan dan perkembangan jemaat.

Dalam membicarakan tentang karunia-karunia Roh dalam jemaat Korintus, Paulus memakai metapora tubuh manusia. Dalam tubuh yang normal, setiap anggota berfungsi sesuai dengan fungsinya yang telah ditentukan Allah. Kaki berfungsi untuk menopang tubuh dan berjalan; mata untuk melihat; mulut untuk mencicipi dan memakan makanan; telinga untuk mendengar dan tangan untuk melakukan atau mengambil sesuatu. Semuanya berjalan secara proposional supaya tubuh dapat bertumbuh sehat. Tidak mungkin fungsi mata didelegasikan kepada kaki atau sebaliknya. Demikian juga tidak mungkin tangan berfungsi untuk mendengar menggantikan telinga. Hal ini mustahil karena akan mengacaukan fungsi anggota tubuh sebagaimana yang telah ditetapkan oleh Allah. Demikian juga dengan karunia Roh Kudus.

Tidak dapat disangkal bahwa setiap orang percaya, seperti yang telah disebutkan sebelumnya, bahwa dalam hal-hal yang khusus dimana ia sangat dibutuhkan untuk suatu bidang pelayanan yang bukan merupakan panggilannya, di mana ia tidak memiliki karunia dalam bidang tersebut, maka Tuhan akan memberikan kemampuan atau karunia baginya untuk melaksanakan pelayanan tersebut. Sebab itu, bilamana seseorang ditugaskan untuk melakukan suatu tugas yang tidak sesuai dengan karunianya dan ia tidak mampu menolaknya, ia perlu berdoa kepada Tuhan agar ia diberikan kemampuan dan karunia untuk bisa dapat melakukan tugas tersebut. Dengan demikian, ia bisa berfungsi seperti yang diharapkan oleh lembaga yang menugaskannya dan nama Tuhan dipermuliakan dalam tugas dan tanggung jawab tersebut.

\section{Berbagai Macam dan Fungsi Karunia Roh}

Sebagai tubuh Kristus, jemaat adalah persekutuan orang-orang percaya, yang telah dipanggil dan dibenarkan Allah untuk menjadi milik-

${ }^{43}$ Bnd. Wagner, Your Spiritual Gifts..., 66. 
Nya. Tujuan panggilan dan pembenaran Allah tersebut adalah untuk kemuliaan Allah. Oleh karena itu, seluruh kehidupan dan aktifitas jemaat di tengah-tengah dunia ini harus senantiasa dihubungkan dengan kemuliaan bagi Allah. Yaitu, dengan mengembangkan persekutuan jemaat dengan Allah dan sekaligus mengembangkan pelayanan jemaat bagi kemuliaan Allah. Kedua hal tersebut tidak dapat dipisah-pisahkan, karena saling berhubungan satu dengan yang lain. Jemaat tidak dapat memuliakan Allah di dalam pelayanannya kalau jemaat tidak hidup dalam persekutuan dengan Allah. Demikian juga sebaliknya, jemaat tidak mungkin menyatakan diri memiliki persekutuan dengan Allah tetapi tidak melayani. ${ }^{44}$ Dengan kata lain, jemaat dalam kehidupannya harus bertumbuh dalam dua segi, yaitu segi kualitatif dan segi kuantitatif. Ia harus bertumbuh secara rohani dan bertumbuh secara jumlah.

Untuk mewujudkan kedua pertumbuhan jemaat tersebut, jemaat tidak sanggup untuk melaksanakannya dengan kemampuannya sendiri. Karena itu, Allah memberikan karunia-karunia Roh kepada setiap anggota jemaat, sesuai dengan kehendakNya. Karena pelayanan rohani adalah pelayanan Allah. Demikian juga "pertumbuhan jemaat adalah karya Allah" 45 dan bukan karya manusia.

Ada empat daftar mengenai karunia-karunia Roh yang dikemukakan oleh rasul Paulus dalam surat-suratnya, yaitu dalam Roma 12:6-8; 1Korintus 12:8-10; 28-30 dan Efesus 4:11. Bilamana diperhatikan akan isi daftar-daftar karunia-karunia Roh tersebut, ternyata tidak ada daftar yang menguraikan secara lengkap jumlah keseluruhan karunia Roh.

Hal tersebut di atas menunjukkan bahwa rasul Paulus, ketika membicarakan karunia-karunia Roh yang ada dalam jemaat, tidak pernah memberikan suatu kepastian mengenai jumlah seluruh karunia Roh yang telah diberikan Allah kepada jemaat. ${ }^{46}$ Ia juga tidak menginformasikan mengenai jenis-jenis karunia-karunia Roh Kudus secara sistematis. Rasul Paulus sangat menekankan keanekaragaman dari karunia-karunia Roh Kudus dalam Gereja sebagai tubuh Kristus (bnd. Rm 12:6; 1Kor 12:4). Keanekaragaman karunia tersebut bertujuan akan pentingnya keharmonisasi karunia-karunia tesebut dalam jemaat sebagai tubuh

44 Bnd. Hatman \& Sutherland, Pedoman Pemuridan (Jakarta: BPK Gunung Mulia, 1976), 35.

45 J.L.Ch. Abineno, Tafsiran Surat Efesus (Jakarta: BPK Gunung Mulia, 1977), 135

46 Wayne Grundem, Systematic Theology, An Introduction to Biblical Doctrine (Leicester: InterVarsity Press, 1994), 1090-1091. 
Kristus. ${ }^{47}$ Sebab itu, jumlah keseluruhan karunia Roh yang telah disebut oleh rasul Paulus dalam Roma 12:6-8; 1Korintus 12:8-10, 28-30; Efesus 4:11 bersama karunia melajang yang disebut dalam 1Korintus 7:7, bukanlah merupakan suatu jumlah keseluruhan dari karunia-karunia Roh yang telah diberikan Allah kepada jemaat-jemaat-Nya.

In the Scriptures of the New Covenant we find different lists of the 'gifts' bestowed upon His church by the risen and glorified Lord. It has often been pointed out that no two of these lists are exactly alike. There is deep suggestiveness and great beauty in this fact. We are all strangely prone to mechanism, and are too fond of tabulating and stating systematically even the things of God. There would have been some sort of satisfaction in having an exhaustive list of His gifts. Yet how sad would it have been, for inevitably we should have spent much time in seeking to place each other by our gifts, or pitying such as seemed to possess none. The gifts were never tabulated exhaustively because they cannot be exhausted; and while today some of the earliest are not found, many new and precious ones are ours. $^{48}$

Oleh karena itu, karunia-karunia Roh tidak hanya terbatas pada segala karunia Roh yang telah disebutkan oleh Paulus, baik yang bersifat spektakular maupun bersifat natural, tetapi juga mencakupi segala talenta atau bakat dan kecakapan orang percaya yang telah dan yang akan dipergunakan serta diubah oleh Allah sebagai karunia Roh. Sehingga segala karunia Roh yang telah Paulus sebutkan hanya merupakan contoh-contoh dari segala karunia Roh yang telah dan yang akan diberikan oleh Allah kepada jemaat. Yang menarik dalam daftar karunia-karunia Roh Kudus yang Paulus sebut, urutan dan isinya sangat berbeda dan bervariasi. Hal ini menunjukkan bahwa Rasul Paulus ingin menegaskan bahwa Roh Kudus ketika menganugerahkan karunia-karunia tersebut kepada setiap jemaat atau anggota jemaat, Ia bertindak dengan cara yang bebas dan beranekaragam sesuai dengan kedaulatan dan kehendak-Nya sendiri bukan kehendak manusia. $^{49}$

47 Ridderbos, Herman., Paul An Outline Of His Theology (Grand Rapids: Eerdmans, 1975), 446-447.

${ }^{48}$ G. Campbell Morgan, dalam Leslie B. Flynn, 19 Gifts Of The Spirit (Wheaton: Victor Books, 1980), 30.

${ }^{49}$ Bnd. Donald Guthrie, Teologi Perjanjian Baru (Jakarta: BPK Gunung Mulia, 1995), 201. 


\section{TINJAUAN TEOLOGIS TERHADAP PANDANGAN NEO PENTAKOSTA TENTANG KARUNIA SPEKTAKULAR}

Dalam bagian ini penulis akan membahas tentang siapa itu NeoPentakosta dilihat dari latarbelakang sejarahnya dan bagaimana pandangan Neo Pentakosta tentang karunia-karunia, secara khusus karunia Spektakular yang dihubungkan dengan Baptisan Roh Kudus sebagai syarat mutlak untuk menerima karunia Roh. Kemudian penulis akan meninjaunya secara teologis pandangan tersebut.

\section{$\underline{\text { Sejarah Singkat Neo-Pentakosta }}$}

Neo Pentakosta atau Pentakosta Baru atau yang dikenal sebagai Gerakan Kharismatik, adalah gerakan orang Kristen yang mengutamakan Baptisan Roh Kudus dan karunia-karunia spektakular, secara khusus karunia berbahasa roh. Penganut-penganutnya, pada mulanya terdapat di hampir semua Gereja tradisional, ${ }^{50}$ kemudian membentuk kelompok tersendiri. Gerakan ini muncul sekitar tahun 1960 dimulai pertama kali di Gereja-gereja Amerika, karena pada saat itu orang-orang mendambakan kehidupan rohani lebih intim dalam hal perasaan kepada Allah. ${ }^{51}$ Pendeta Dennis Bennett, dari Gereja Episkopal St. Markus, disebut-sebut sebagai tokoh munculnya Gerakan Neo Pentakosta atau Kharismatik. Lewat kesaksiannya tentang pengalaman menerima kuasa dan Baptisan Roh, termasuk karunia berbahasa roh, menggoncangkan jemaat tersebut serta mempengaruhi beberapa jemaat Episkopal. Pengaruh ini mulai di kota Los Angeles, California kemudian di kota Seattle, negara bagian Washington. Terobosan awal mulai dari Gereja Episkopal meluas pengaruhnya ke Gereja Protestan arus utama lainnya, yaitu Metodis, Lutheran, Presbyterian dan Mennonit. $^{52}$

Gerakan ini merupakan perkembangan dari Gerakan Pentakosta sehingga garis besar ajarannya sama dengan ajaran Pentakosta. ${ }^{53}$ Yang membedakan antara Neo-Pentakosta dengan Gerakan Pentakosta adalah Gerakan Pentakosta cendrung membentuk denominasi tersendiri sedangkan Neo-Pentakosta atau Kharismatik tersebar di banyak denominasi Gereja

50 Rudy Budiman, Menentukan Sikap Terhadap Gerakan Kharismatik, dalam Gerakan Kharismatik, Apa Itu? (Jakarta: BPK Gunung Mulia, 1980), 170.

51 J. Stephen Lang, 1001 Hal yang Ingin Anda Ketahui Tentang Roh Kudus (Jakarta: Immanuel, 2002), 259.

52 Jan Aritonang, Berbagai Aliran Di dalam Dan Sekitar Gereja (Jakarta: BPK Gunung Mulia, 1995), 202-204.

${ }^{53}$ Budiman, Menentukan Sikap Terhadap Gerakan..., 171. 
termasuk Katolik. Untuk membedakan dari Gerakan ini dari Gerakan Pentakosta yang lama, maka ia biasanya disebut Gerakan Pentakosta Baru. $^{54}$ Selanjutnya, menurut Abineno bahwa timbulnya Gerakan Pentakosta Baru atau Gerakan Kharismatik disebabkan oleh berbagai hal, baik karena keadaan di masyarakat, juga masalah di Gereja dan theologianya. Oleh keadaan letih menghadapi hal tersebut terciptalah kemungkinan dan ruang untuk timbulnya rupa-rupa hal dalam Gereja. Salah satunya adalah Gerakan Kharismatik. ${ }^{55}$ Gerakan ini merupakan suatu gerakan yang penuh dinamika, dan merupakan suatu kekuatan baru dalam sejarah kehidupan Gereja sejak tahun 1960.

Tujuan utama dari Neo-Pentakosta atau Gerakan Kharismatik adalah untuk menghidupkan kembali semangat Perjanjian baru jemaat Kristen yang mula-mula, sebagaimana yang diberitakan dalam Kisah Para Rasul. ${ }^{56}$ Mereka ingin memberikan kepada orang percaya suatu penghayatan baru dari peristiwa Pentakosta. Penghayatan iman yang intensif disertai dengan rupa-rupa karunia spektakular, terutama berbahasa Roh. Hal ini sering dihubungkan dengan apa yang dikenal sebagai Baptisan Roh Kudus. ${ }^{57}$

\section{Pandangan Neo-Pentakosta}

\section{Karunia Roh Dan Baptisan Roh Kudus}

Menurut pengajaran Neo-Pentakosta/Kharismatik, pengalaman baptisan Roh adalah merupakan suatu pengalaman yang berbeda dan tidak sama dengan pekerjaan Roh Kudus di dalam proses kelahiran baru, yang menjadikan seseorang bertobat dan percaya kepada Kristus untuk menerima keselamatan. $^{58}$

${ }^{54}$ J.L. Ch. Abineno, Gerakan Pentakosta Dan Gerakan Pentakosta Baru, dalam Gerakan Kharismatik, Apa Itu, (Jakarta: BPK Gunung Agung, 1980), 281.

55 Abineno, Gerakan Pentakosta Dan..., 290-292.

56 Homan Rubyono, Dari Baptisan Roh Menuju Kepenuhan Roh (Bandung: Yayasan Kalam Hidup, 1999), 17.

57 John F. MacArthur, Jr., The Charismatics, A Doctrinal Perspective (Grand Rapids: Zondervan, 1978), 13

${ }^{58}$ Bnd. Bina Oikoumene no: 3, Gerakan Pentakosta dan Baptisan Dengan Roh (Jakarta: Dept. Keesaan Dan Kesaksian DGI, t.t.), 6; Rubyono, Ibid, 30; Rudy Budiman, Menentukan Sikap Terhadap Gerakan Kharismatik, Dalam Gerakan Kharismatik, Apakah itu? ( Jakarta: BPK Gunung Mulia, 1980), 174. 
Pandangan ini misalnya nampak dalam penguraian dari salah seorang pemimpin dari gerakan ini, L. Christenson, Pendeta dari Gereja Trinity Lutheran di California. Dalam bukunya Speaking in Tongues ia menyatakan sebagai berikut: "Beyond conversion, beyond the assurance of salvation, beyond having the Holy Spirit, there is a baptism with the Holy Spirit." $" 59$

Hal yang sama dikemukakan oleh Don Basham, dalam bukunya $A$ Handbook on Holy Spirit Baptism ketika menjawab pertanyaan tentang apakah penting baptisan Roh Kudus bagi keselamatan, ia menjawab sebagai berikut:

No, baptism in the Holy Spirit is not essential for salvation. Salvation, or conversion, or the acceptance of Christ as Lord and Savior is a separate, prior experience. Millions of Christians who love and serve Jesus Christ as Savior have not received the baptism in the Holy Spirit. The New Testament makes it plain that baptism in the Holy Spirit is a second work of grace which follows conversion. ${ }^{60}$

Oleh karena itu, bagi gerakan Kharismatik, pengalaman baptisan Roh Kudus adalah merupakan suatu pengalaman yang kedua atau the second blessing bagi setiap orang percaya. Sehingga tidak semua orang percaya mengalami akan hal tersebut, melainkan hanya kepada mereka yang sungguh-sungguh mau mencari dan mengharapkannya dengan iman. ${ }^{61}$ Dengan kata lain, hanya mereka yang mempunyai taraf iman yang lebih 'sempurna' yang akan menerima dan mengalami Baptisan Roh.

Neo-Pentakosta membedakan antara karya permulaan Roh Kudus, dalam proses kelahiran baru dengan karya Roh Kudus yang dianggap 'sempurna' dalam Baptisan Roh kudus, yaitu karena dalam Baptisan Roh Kudus nyata sekali pengalaman orang percaya mengalami kekayaan rohani dan kuasa Allah. Dalam Baptisan Roh kudus, orang percaya mengalami kuasa dan kelimpahan karunia-karunia Roh Kudus, dan manifestasi pertama dari kenyataan itu adalah menerima karunia berbahasa Roh. Dengan demikian, syarat utama bagi setiap orang percaya untuk menerima karuniakarunia Roh Kudus adalah harus mengalami Baptisan Roh Kudus.

${ }^{59}$ L. Christenson, Speaking in Tongues (Minneapolis: Dimension Books, 1975),

60 Don Basham, A Handbook on Holy Spirit Baptism (Monroeville: Whitaker Books Publisher, 1973), 15.

${ }^{61}$ Bnd. Robert Dalton, Tongues Like As of Fire, 70, dalam Kohn F. MacArthur, Jr., The Charismatics, A Doctrinal Perspective (Grand Rapids: Zondervan, 1980), 119. 
Dasar pandangan gerakan Kharismatik mengenai hal tersebut adalah pengalaman orang-orang percaya yang disaksikan oleh kitab Kisah Rasul. ${ }^{62}$ Searah dengan hal ini, Abineno menyatakan, "Kitab ini, menurut mereka, adalah kunci untuk mengerti segala sesuatu yang dikatakan oleh Perjanjian Baru tentang ajaran itu."63

Pengalaman-pengalaman orang percaya yang dimaksud adalah: pertama, mereka menunjuk kepada pengalaman 120 murid Tuhan Yesus, yang di dalamnya termasuk para Rasul Yesus. Ke-120 murid Yesus ini sudah menjadi murid Yesus dan sudah menerima Roh Kudus, tetapi Yesus masih memerintah mereka untuk menantikan janji Bapa, yaitu untuk menerima baptisan Roh Kudus.

On the day of Christ's ascension, every one of the Apostles could have made the same confession: "I believe on the Lord Jesus. I'm saved. I'm going to heaven. I have the Holy Spirit (see John 20:22)". Yet charged them "not to depart from Jerusalem, but to wait for the promise of the Father, which, he said, 'you heard from me, for John baptized with water, but before many days you shall be baptized with the Holy Spirit. ${ }^{64}$

Kemudian, mereka menunjuk kepada orang Kristen di Samaria, yang dikemukakan dalam Kisah Rasul 8:12-17. Dikatakan dalam ayat 12 bahwa mereka telah percaya dan memberi dirinya dibaptis. Tetapi dalam ayat 16 dinyatakan bahwa Roh Kudus belum turun atas mereka, karena hanya dibaptis dalam nama Tuhan Yesus. Saat Petrus dan Yohanes berdoa dan menumpangkan tangan, mereka menerima Roh Kudus (ay. 15, 17).

Selanjutnya, dikemukakan mengenai pengalaman keluarga Kornelius dan sahabat-sahabatnya. Dalam Kisah Para Rasul 10:2, dikatakan bahwa Kornelius beserta keluarganya adalah orang yang takut akan Allah dan senantiasa berdoa kepada Allah. Namun demikian, mereka baru menerima baptisan Roh Kudus setelah mendengar pemberitaan Petrus, yang membawa mereka untuk beriman kepada Kristus.

Yang terakhir, yang paling diandalkan oleh gerakan ini untuk membuktikan akan pentingnya pengalaman baptisan Roh dan yang hanya dialami oleh mereka yang sungguh beriman kepada Kristus, adalah Kisah Rasul 19:1-6. Dinyatakan dalam ayat-ayat tersebut bahwa Paulus bertemu

62 Bnd. Frederick Dale Bruner, A Theology of the Holy Spirit (Grand Rapids: Eerdmans, 1970), 61.

63 J.L.Ch. Abineno, "Gerakan Pentakosta dan Baptisan dengan Roh.” dalam Bina Oikumene. No. 3 (Jakarta Pusat: Departemen Keesaan dan Kesaksian DGI, 1978), 13.

${ }^{64}$ Christenson, Speaking In Tongues..., 37. 
dengan 12 murid yang telah dibaptis dengan baptisan Yohanes, baptisan pertobatan, namun belum memiliki Roh Kudus. Setelah mendengar pemberitaan Paulus tentang Kristus dan dibaptis dalam nama Tuhan Yesus, baru Roh Kudus turun ke atas mereka dan mereka mengalami baptisan Roh Kudus, yang ditandai dengan berkata-kata dalam bahasa roh dan bernubuat.

Melalui beberapa kesaksian tersebut di atas, gerakan NeoPentakosta/Kharismatik mengambil kesimpulan bahwa pengalaman baptisan Roh, adalah merupakan suatu pengalaman kedua dan berbeda dengan pengalaman ketika percaya kepada Kristus dan menerima keselamatan-Nya. Hal ini makin jelas nampak dari pernyataan Ariel Edvardsen sebagai berikut:
Alkitab dengan jelas mengajarkan bahwa Kelahiran Baru dan Baptisan Roh merupakan dua pengalaman yang berbeda......Jika kita akan DIPENUHI ATAU DIBAPTIS OLEH ROHULKUDUS maka kita pertama-tama harus DILAHIRKAN OLEH ROHULKUDUS. Dan mujizat Kelahiran Baru berlaku ketika kita bertobat lalu kemudian juga dapat dibaptis dengan Rohulkudus... Di sini kita melihat bahwa pertama-tama PERTOBATAN dan barulah setelah pertobatan ada Baptisan Rohulkudus." 65

Alasan mengapa mereka sangat menekankan pengalaman baptisan Roh, antara lain nampak dalam uraian Don Basham berikut ini:

Essentially, baptism in the Holy Spirit is a doorway leading from a natural realm into a supernatural realm of life and experience. The average Christians, although truly professing Christ, operates largely on his own power, making his own decisions, living by his own strength, and controlling his own life. But through the baptism in the Holy Spirit the Christian steps out of this natural realm into a realm where he can begin to experience the supernatural gifts and powers of God's Holy Spirit. ${ }^{6}{ }^{6}$

Hal yang sama dikemukakan oleh Robert C. Frost bahwa "We must also know Him, however, as our personal Baptizer if 'power' of God's Spirit is to find full expression in our lives." 67

Bagi gerakan Kharismatik baptisan Roh Kudus sangat dibutuhkan untuk dapat menerima kepenuhan kuasa Roh Kudus dan karunia-karunia-

22.

${ }^{65}$ Ariel Edvardsen, Baptisan Dan Karunia Rohulkudus (Jakarta: Immanuel, t.t.),

${ }^{66}$ Basham, A Handbook On Holy..., 4.

${ }^{67}$ Robert C. Frost, Aglow with the Spirit, dikutip dari Anthony A. Hoekema, Holy Spirit Baptism (Grand Rapids: Eerdmans, 1972), 12. 
Nya, sehingga memungkinkan seseorang siap untuk menunaikan tugasnya di bidang kesaksian dan pelayanan bagi kemuliaan Allah. ${ }^{68}$ Dengan kata lain, tanpa pengalaman baptisan Roh tidak mungkin seseorang dapat menerima kuasa Roh Kudus dan karunia-karunia Roh Kudus, sebagai perlengkapan di bidang kesaksian dan pelayanan. Ajaran ini menimbulkan suatu pengertian yang baru dalam penumatologi bahwa hanya orang-orang yang telah mengalami karya Roh kudus yang 'sempurna' dalam baptisan Roh, mengalami second blessing yang memiliki karunia-karunia Roh, karena karunia-karunia Roh diterima melalui baptisan Roh. ${ }^{69}$ Berarti tidak semua orang percaya menerima dan memiliki karunia-karunia Roh bilamana mereka baru mengalami 'karya permulaan' Roh kudus, yaitu kelahiran baru.

\section{Karunia Roh dan Kualitasnya}

Kecenderungan untuk membeda-bedakan dan mengutamakan beberapa karunia-karunia Roh tertentu, sebagaimana yang terjadi dalam kehidupan jemaat di Korintus, nampak dalam pandangan gerakan NeoPentakosta/Kharismatik.

Menurut pandangan gerakan ini, karunia-karunia Roh yang diberikan Allah kepada orang percaya atau jemaat, hanya sebatas sembilan macam karunia Roh. $^{70}$ Yaitu, kesembilan macam karunia Roh yang disebutkan rasul Paulus dalam 1Korintus 12:8-10 : Karunia untuk berkatakata dengan hikmat, karunia untuk berkata-kata dengan pengetahuan, karunia iman karunia penyembuhan, karunia mujizat, karunia bernubuat, karunia berkata-kata dengan bahasa roh, dan karunia untuk menafsirkan bahasa roh.

Dan karena Allah telah memberikan Rohulkudus kepada setiap Gereja setempat maka kesembilan karunia itu bekerja sepenuhnya di dalam setiap Gereja itu. Pendeta T.B. Barratt yang terkenal mengatakan:' Kita harus mengambil kesembilan' karunia di dalam I Korintus 12, mencelupkannya di dalam pasal 13 (kasih) lalu menerapkannya seperti di dalam pasal 14'. Inilah maksud Allah

${ }^{68}$ Bnd. Abineno, "Gerakan Pentakosta dan Baptisan...," 3.

${ }^{69}$ Bnd. Bridge \& David Phypers, Karunia-karunia dan ..., 120.

70 Bnd. J.L.Ch. Abineno, Karunia-karunia Roh Kudus (Jakarta: BPK Gunung Mulia, 1980), 9, 12; Budiman, Menentukan Sikap Terhadap..., 179; Christenson, Speaking In Tongues..., 114,117; Howard M. Ervin, These are not Drunken as Ye Suppose (Plainfiel, N.J: Logos International, 1968), 216; Kevin and Dorothy Ranagham, Catholic Pentecostals (Paramus, N.J.: Paulist Press, 1969), 160. 
dengan karunia-karunia Roh itu. Setiap Gereja yang berhadap untuk mengalami dan hidup di dalam kegerakan Perjanjian baru yang kini sedang berlangsung, haruslah mempersilahkan kesembilan karunia Roh itu bekerja di dalam Gereja. Bila karunia-karunia ini bekerja di dalam Gereja anda maka anda akan kembali kepada kegerakan rohani kerasulan, Kegerakan Karunia Rohani. ${ }^{71}$

Dari antara kesembilan karunia Roh Kudus tersebut, karuniakarunia Roh Kudus yang bersifat spektakular dianggap sebagai karuniakarunia yang paling penting. ${ }^{72}$ Khusus karunia untuk berkata-kata dengan bahasa roh, untuk hampir seluruh tokoh gerakan Kharismatik mempunyai pandangan bahwa hal itu mutlak harus dimiliki oleh setiap orang percaya, sebagai bukti pengalaman baptisan dengan Roh Kudus. ${ }^{73}$ Pandangan mengenai hal tersebut, antara lain nampak dalam jawaban Don Basham, ketika ditanya mengenai "apakah mungkin seseorang menerima baptisan dengan Roh Kudus tanpa berkata-kata dengan bahasa Roh?" Ia menjawab sebagai berikut:

So we must admit that the baptism in the Holy Spirit can be received without the manifestation of tongues, but we encourage no one to seek the baptism without expecting tongues. Both our understanding of spiritual gifts and our willingness to receive then affect what gifts and manifestations will appear. SOMETHING IS MISSING IN YOUR SPIRITUAL LIFE IF YOU HAVE RECEIVED THE HOLY SPIRIT YET HAVE NOT SPOKEN IN TONGUES... We encourage everyone seeking to be filled with this Holy Spirit to seek the baptism on scriptural terms, fully expecting to speak in tongues when they receive. ${ }^{74}$

Pandangan yang sama dikemukakan oleh Rev. Edwin B. Stube, Direktur dari Blessed Trinity Society sebagai berikut:

In the New Testament, the standard sign or evidence of the baptism of the Holy Spirit is that of speaking with other tongues as the Spirit given utterance.... It is clearly God's intention that all believers should receive the Baptism of the Holy Spirit with the sign which the New Testament indicates (namely, the sign of tongue-speaking) ${ }^{75}$

${ }^{71}$ Edvardsen, Baptisan Dan Karunia..., 11.

${ }^{72}$ Bnd. Abineno, Karunia-karunia Roh..., 9.

73 Bnd. Anthony A. Hoekema, What About Tongue-Speaking (Grand Rapids: Eerdmans, 1966), 48.

${ }^{74}$ Basham, A Handbook On Holy..., 63-64.

${ }^{75}$ Edwin B. Stube, dalam Anthony A. Hoekema, Ibid., 46-47. 
Menurut Rudy Budiman, bahwa kecenderungan dari gerakan Kharismatik untuk mengutamakan kesembilan karunia yang disebutkan dalam 1Korintus 12:8-10 dan membedakannya dari karunia-karunia Roh yang lain, yang Paulus sebutkan dalam 1Korintus 12:28; Roma 12:6-8 seperti karunia melayani, karunia memimpin, karunia mengajar, karunia menasehati, membagi-bagikan sesuatu, kemurahan; antara lain karena di dalam penampilan kesembilan karunia tersebut, bersifat supranatural dan nampak sekali kuasa ajaib yang bekerja. Sebaliknya, karunia-karunia yang lain yang bersifat natural, tidak ada hal-hal yang luar biasa di dalam penampilannya, yang membuktikan akan adanya pekerjaan-pekerjaan kuasa ajaib. $^{76}$ Implikasinya, segala karunia Roh Kudus yang di dalamnya tidak menampakkan keajaiban Tuhan atau yang bersifat supra-natural, dianggap kurang bernilai atau bukan karunia Roh. Segala karunia yang di dalamnya nampak keajaiban Tuhan atau bersifat supra-natural, itulah karunia Roh Kudus. Karena itu, kesembilan karunia yang disebut dalam 1Korintus 12:8-10, dianggap lebih tinggi atau lebih berkualitas daripada karuniakarunia Roh yang lain. Karena ia bersifat supranatural dan sepktakular, yang lain bersifat natural dan non spektakular.

\section{Tinjaun Teologis Terhadap Pandangan Neo-Pentakosta}

\section{Karunia Roh dan Baptisan Roh}

Dalam Perjanjian Baru, istilah baptisan Roh Kudus atau dibaptis dengan Roh Kudus, dipergunakan sebanyak 7 kali. 5 kali dipergunakan dalam bentuk nubuatan yang berkaitan dengan janji Allah mengenai baptisan dengan Roh Kudus yang akan dilaksanakan oleh Kristus bagi setiap orang percaya: 4 kali berkaitan dengan ucapan Yohanes Pembaptis dan 1 kali diucapkan oleh Kristus sendiri sebelum peristiwa Pentakosta. (Mat 3:11; Mrk 1:8; Luk 3:16; Yoh 1:33; Kis 1:5). Satu kali dipergunakan oleh rasul Petrus di dalam Kisah Rasul 11:16, ketika memberikan laporan kepada saudara-saudara seiman di Yerusalem, tentang pengalaman keluarga Kornelius dan sahabat-sahabatnya menerima baptisan Roh Kudus. Dan yang terakhir, dalam bentuk pengajaran, rasul Paulus mempergunakan istilah tersebut sebanyak 1 kali dalam 1Korintus 12:13. Yaitu, berkaitan dengan pengalaman semua orang percaya yang dalam satu Roh telah dibaptis menjadi satu di dalam tubuh Kristus.

\footnotetext{
${ }^{76}$ Budiman, Menentukan Sikap Terhadap..., 224-225.
} 
Bilamana diperhatikan semua ayat-ayat Firman Tuhan tersebut di atas, nampak bahwa semuanya saling berkaitan satu dengan yang lain. Apa yang telah dinubuatkan oleh Yohanes dan yang dijanjikan oleh Kristus, telah digenapi di dalam peristiwa Pentakosta dan pengalaman keluarga Kornelius dan sahabat-sahabatnya. Sedangkan apa yang diajarkan oleh rasul Paulus tentang dalam satu Roh semua orang percaya telah dibaptis menjadi satu tubuh, adalah merupakan suatu kesimpulan pengajaran tentang apa yang telah terjadi, sebagai akibat adanya Roh Kudus yang telah dicurahkan melalui peristiwa Pentakosta, sebagai penggenapan nubuatan Yohanes dan janji Kristus. ${ }^{77}$

Karena itu, istilah dibaptis dengan Roh Kudus yang dipergunakan oleh Yohanes dan Kristus, maupun Petrus, pada dasarnya sama dengan istilah yang dipergunakan Paulus dalam 1Korintus 12:13. ${ }^{78}$

Lebih lanjut kita akan menyelidiki apa yang dimaksud Paulus dengan istilah dibaptis dengan Roh dalam 1Korintus 12:13. Dalam ayat tersebut, Paulus menyatakan: "Sebab dalam satu Roh kita semua, baik orang Yahudi, maupun orang Yunani, baik budak, maupun orang merdeka, telah dibaptis menjadi satu tubuh kita semua diberi minum dari satu Roh."

Rasul Paulus memakai istilah kita semua adalah untuk menunjuk kepada dirinya dan semua orang percaya yang ada di jemaat Korintus tanpa terkecuali. Tanpa membedakan keadaan status sosial dan keadaan rohaninya. Sehingga hal tersebut termasuk semua anggota jemaat di Korintus, yang dalam 1Korintus 3:1 disebut oleh Paulus sebagai manusia duniawi, manusia yang penuh dengan segala macam dosa (bnd. 1Kor 3:3, 4:18, 5:1, 6:12-18, 10:14-22, 11:17-22, dst). Sebab itu, baptisan Roh Kudus bukan hanya dialami oleh beberapa orang percaya saja, yang mempunyai taraf iman dan kerohanian tinggi. Baptisan Roh Kudus juga mencakupi semua orang percaya, yang ada di dalam Kristus. Sebab itu, tepat apa yang dikatakan oleh Michael Green: "So baptism with the Holy Spirit is not a second-stage experience for some Christians, but an initiatory experience for all Christians. Without it we are not Christians at all."79

Satu hal yang menarik dalam 1Korintus 12:13, yaitu tentang istilah telah dibaptis dan diberi minum. Keduanya mempunyai aspek aorist dan arahnya pasif, yang dihubungkan dengan kata penghubung kai. Dengan

77 Bnd. J. Oswald Sanders, The Holy Spirit and His Gifts (London: Marshall, Morgan \& Scott, 1970), 65-66

78 Bnd. Albert Barnes, Barnes on the New Testament, I Corinthians (Grand Rapids: Baker Book House, 1979), 233.

${ }^{79}$ Michael Green, I Believe in the Holy Spirit (Grand Rapids: Eerdmans, 1980), $141-142$ 
demikian kedua hal tersebut adalah merupakan suatu kejadian yang terjadi bersama-sama (simultan) pada masa yang lampau, sekali untuk seterusnya. Pengertian "dalam satu Roh kita semua telah dibaptis menjadi satu tubuh," sebenarnya mempunyai kesamaan pengertian dengan apa yang dikemukakan dalam Galatia 3:27; Roma 6:3, "dibaptis di dalam Kristus." 80 Karena, pada waktu seseorang percaya kepada Kristus dan dibaptis di dalam Kristus, pada waktu itu juga ia dibaptis dengan Roh Kudus. Kedua baptisan tersebut saling berhubungan dan karena itu tidak dapat dipisahkan satu sama yang lain, sebagaimana dikatakan Frederick Dale Bruner:

Appropriate to the Christological character and mission of the Holy Spirit, the Baptism of the Holy Spirit is the baptism the believer into Christ. Yet baptism into Christ can no more be separated from baptism into the Holy Spirit than Christ can separated from the Holy Spirit. For in the depths the name by which we are baptized is one (I Cor 6:17, 15:45, II Cor 3:17-18; cf. the singular "name" in Matt 28:18). For Christ and the Spirit are not divided that each must separately and at appropriate times baptize into each other. ${ }^{81}$

Selanjutnya, pengertian diberi minum dari satu Roh mempunyai kaitan dengan apa yang Yesus nyatakan dalam Yohanes 4:14, 7:37-39, yaitu tentang pemberian Roh Kudus dan keselamatan bagi setiap orang yang percaya kepada Kristus. ${ }^{82}$ Karena Istilah telah dibaptis dan diberi minum mempunyai aspek aorist, maka pengertian "dalam satu Roh kita semua telah dibaptis menjadi satu tubuh, dan kita semua telah diberi minum dari satu Roh" adalah menunjuk kepada satu peristiwa yang telah terjadi serentak (simultan) dalam kehidupan setiap orang percaya pada waktu ia diselamatkan. Maksudnya, pada waktu seseorang percaya kepada Kristus, pada saat itulah ia menerima keselamatan dan Roh Kudus, dan menjadi anggota jemaat, sebagai tubuh Kristus. Dan hal inilah yang dimaksud dengan baptisan dengan Roh Kudus. ${ }^{83}$

Jadi, istilah dibaptis dengan Roh Kudus sama pengertiannya dengan menerima Roh Kudus, bahkan sama dengan diurapi Roh Kudus dan dimeteraikan dengan Roh Kudus, sebagaimana yang dinyatakan rasul

${ }^{80}$ Bnd. A.T. Robertson, Word Pictures in the New Testament. Vol. IV (Grand Rapids: Baker Book House, 1931), 171.

${ }^{81}$ Bruner, A Theology Of The Holy Spirit..., 293.

82 Bnd. Lenski, The Interpretation Of St. Paul's..., 516.

${ }^{83}$ Bnd. Galatia 3:2-5,14,29, Kisah Rasul 2:38-39, 11:14-18: menerima Roh Kudus yang dijanjikan Allah, pada waktu percaya, sama dengan dibaptis dengan Roh Kudus. 
Paulus dalam Efesus 1:13; 2Korintus 1:21-22; Roma 8:15. ${ }^{84}$ Semua pengalaman tersebut adalah semata-mata pemberian Allah berdasarkan kasih dan anugerah-Nya, bukan berdasarkan kebaikan dan jasa dari setiap orang percaya. Karena itu, baptisan dengan Roh Kudus bukanlah sesuatu yang diusahakan ataupun harus dicapai sebagai pengalaman yang kedua bagi setiap orang percaya. Melainkan semua orang percaya telah dibaptis dengan Roh Kudus atau telah memiliki Roh Kudus, sebagai pemberian Allah. Inilah yang dimaksud oleh rasul Paulus ketika ia mempergunakan arah pasif untuk kedua istilah telah dibaptis dan diberi minum dalam satu Roh, di dalam 1Korintus 12:13.

Lalu bagaimana dengan segala pengalaman orang percaya yang dikemukakan dalam Kis 2 berkaitan dengan pengalaman murid-murid Yesus, pasal 8 berkaitan dengan murid-murid di Samaria, pasal 10 berkaitan dengan keluarga Kornelius dan sahabat-sahabatnya dalam pasal 19 berkaitan dengan murid-murid Yohanes di Efesus? Untuk menjawab pertanyaan ini, maka hal tersebut akan dibahas selanjutnya di bawah ini.

Satu hal yang perlu menjadi pegangan di dalam menafsirkan semua pengalaman orang percaya dalam Kisah Para Rasul, yaitu bahwa semua pengalaman praktis tersebut tidak dapat menjadikan suatu patokan untuk suatu pengajaran mutlak tentang baptisan dengan Roh Kudus. Karena hal tersebut bukan merupakan uraian-uraian dan kesimpulan yang bersifat dogmatis, sebagaimana yang dikatakan oleh D. Scheunemann:

Contoh-contoh itu menunjukkan bahwa Roh Kudus dapat bekerja demikian, namun tidak harus bekerja sedemikian. "Dimana ada Roh Allah disitu ada kemerdekaan". Hermeneutik yang bertanggung jawab dan berorientasi kepada Alkitab membangun suatu pengajaran Kristen hanya berdasarkan atas bagian-bagian Alkitab yang bersifat didaktis (bersifat ajaran), dan bukan atas kejadian-kejadian historis yang diceritakan dalam Alkitab. Karena itu, dari peristiwa-peristiwa yang dicatat dalam Kisah Para Rasul, kita tidak boleh menarik

84 "Baptisan Roh tidak terbatas pada peristiwa Petakosta, tetapi masih terjadi terus menerus dalam seraja gereja dan juga berulang-ulang disebut dalam Perjanjian Baru, Cuma dengan istilah-istilah lain. Di Galatia 3:14 misalnya disebut 'menerima Roh yang telah dijanjikan.' Ini mengingat kita pada Kisah Rasul 2:33,39, di mana Roh yang yang dijanjikan dicurahkan pada hari Pentakosta... Istilah lain lagi adalah 'Roh Kudus turun atas; (Kis 11:15; 19:6)...Istilah yang juga dipergunakan Paulus adalah 'mengurapi dengan Roh Kudus' (2Kor 1:21b,22), 'memeteraikan dengan Roh Kudus'(Ef 1:13b; 14; 4:20). Kata-kata kerja (dalam bahasa Yunani) ini dipakai dengan bentuk waktu Aorist yang menunjukkan, bahwa pengurapan atau pemeteraian itu terjadi satu kali pada masa yang lampau, dengan perkataan lain, pada saat orang dibaptis dengan Roh Kudus.” Budiman, Menentukan Sikap Terhadap..., 174. 
kesimpulan-kesimpulan yang bersifat dogmatis tentang penerimaan Roh Kudus serta akibat-akibatnya, sebagai kaidah yang mutlak bagi setiap orang Kristen. ${ }^{85}$

Membahas pengalaman orang percaya dalam Kisah Rasul haruslah dibahas secara bertanggung jawab dengan melihat seluruh kesaksian Alkitab. Walaupun apa yang dikemukakan oleh penulis Kisah Rasul adalah fakta sejarah. Namun, hal tersebut adalah merupakan suatu ungkapan historis dan bukan didaktis yang normatif.

\section{Pengalaman 120 Murid Kristus Dalam Kisah Para Rasul 2}

Merupakan suatu kenyataan bahwa sebelum peristiwa Pentakosta, dimana 120 murid Kristus dibaptis dengan Roh Kudus, mereka adalah murid-murid Kristus yang telah percaya kepada-Nya. Kesebelas murid-Nya telah dipilih dan ditetapkan sebagai rasul-rasul-Nya untuk memberitakan Injil ke seluruh dunia (Mat 10:1-4, 28:16-20). Mereka adalah dasar Gereja (Mat 16:18-19). Mereka pernah melayani dan memberitakan Injil dengan kuasa Allah (Mrk 6:6-13, Luk 9:1-6, Mat 10:5-15) dan setan-setan takluk kepada mereka, karena nama Kristus. (Luk 10:17). Mereka adalah saksi mata kematian, kebangkitan dan kenaikan Yesus Kristus ke surga. (Mrk 16:12-20; Luk 24:36-53; Yoh 20:19-20, 26-29; Kis 1:11; 1Kor 15:5-7). Namun situasi mereka berbeda dengan situasi orang percaya masa kini. Pada saat itu, 120 murid Tuhan Yesus hidup dalam situasi dimana Roh Kudus belum dicurahkan. Kedua belas Rasul dan murid-murid Tuhan Yesus yang lain, masih harus menantikan janji Tuhan Yesus tentang baptisan dengan Roh Kudus yang akan mereka alami. Hal itu terwujud pada peristiwa Pentakosta. Dan yang menyebabkan "adanya tenggang waktu antara percayanya ke 120 orang itu dengan turunnya Roh Kudus adalah disebabkan oleh penentuan waktu dalam urutan sejarah keselamatan Kristus, dan bukan oleh perbedaan taraf iman." 86 Oleh karena itu, pengalaman murid-murid Yesus tidak dapat diterapkan pada orang percaya yang hidup pada masa kini. ${ }^{87}$

${ }^{85}$ Scheunemann, Sungai Air..., 211-212.

${ }^{86}$ R. Budiman, Menentukan sikap terhadap gerakan Kharismatik, dalam buku: Gerakan Kharismatik Apakah Itu (Jakarta: BPK Gunung Mulia, 1980), 191. Press, 1957), 73.

87 Bnd. Rene Pache, The Person and work of the Holy Spirit (Chicago: Moody 


\section{$\underline{\text { Pengalaman Orang Percaya di Samaria Dalam Kisah Para Rasul } 8}$}

Banyak teolog berpendapat bahwa bagian Firman Tuhan tersebut merupakan suatu bagian yang agak sulit untuk ditafsirkan. ${ }^{88}$ Karena situasi yang terjadi pada saat itu agak berbeda dengan kebiasaan yang seharusnya terjadi. Mereka yang sudah percaya kepada Kristus dan telah dibaptis di dalam Kristus, tetapi kenyataannya belum menerima Roh Kudus. Padahal mereka hidup dalam situasi dimana Roh Kudus sudah dicurahkan oleh Kristus, bagi setiap orang yang percaya kepada-Nya. Sehingga kasusnya berbeda dengan yang dialami oleh ke 120 murid Yesus di Yerusalem. Hal ini mengakibatkan terjadi perbedaan pendapat di antara para ahli teologi tentang sebab-sebab Roh Kudus belum diberikan kepada orang di Samaria.

Ada yang menyatakan bahwa yang menyebabkan orang percaya di Samaria belum dibaptis dengan Roh Kudus, adalah karena mereka belum sungguh-sungguh bertobat dan percaya kepada Kristus. Mereka dikatakan percaya, dalam ayat 12 , tetapi percaya mereka tertuju kepada Filipus dan bukan kepada Kristus. Dan juga respons mereka terhadap apa yang diberitakan Filipus adalah hanya merupakan suatu luapan emosi saja dan bukan berdasarkan iman. ${ }^{89}$

Sebaliknya, ada yang menyatakan bahwa sebenarnya orang-orang di Samaria sungguh sudah percaya kepada Kristus. Karena itu, sukacita yang dinyatakan dalam ayat 8 adalah sukacita orang yang telah bertobat, sebagaimana yang dinyatakan dalam Kisah Para Rasul 2:46-47. Yang menyebabkan mereka belum dibaptis dengan Roh Kudus, adalah merupakan suatu maksud Tuhan. Yaitu, supaya melalui penumpangan tangan dan doa dari kedua rasul tersebut, orang percaya di Samaria mengetahui posisi dan wibawa dari para rasul, yang telah ditetapkan sebagai dasar Gereja. Dan sekaligus untuk mempersatukan kedua Gereja, Gereja Yahudi di Yerusalem dan non Yahudi di Samaria, di dalam Kristus, sebagai tubuh Kristus. ${ }^{90}$

Untuk memecahkan masalah tersebut di atas dan mengetahui pengertian yang sebenarnya, maka perlu dilihat kembali apa kata Firman Tuhan itu sendiri.

${ }^{88}$ Abineno, Gerakan Pentakosta \& Baptisan..., 22, Bridge \& David Phypers, Karunia-karunia Roh..., 135.

${ }^{89}$ James D.G. Dunn, Baptism in the Holy Spirit (Philadelphia: The Westminster Press, 1970), 63.

${ }^{90}$ David Brown, A Commentary, Critical, Experimental, and Practical on the Old and New Testament. Vol.III, Part Two (Grand Rapids: Eerdmans, 1978), 49-50. 
Dalam ayat 12, dikatakan bahwa orang Samaria percaya kepada Filipus, yang memberikan Injil tentang nama Yesus Kristus. Dalam struktur kalimat tersebut, nampaknya memang percaya mereka tertuju kepada Filipus. Tetapi kalau diperhatikan lebih teliti akan kalimat tersebut, nyata bahwa mereka tidak hanya percaya kepada Filipus; melainkan kepada Filipus, yang memberitakan Injil Kerajaan Allah dan Yesus Kristus.

Selanjutnya, dalam ayat 15-16, dikatakan bahwa Petrus dan Yohanes berdoa supaya orang percaya di Samaria memperoleh Roh Kudus. Keterangan lebih lanjut tidak ada, sehingga penekanannya hanya tertuju kepada mendoakan mereka. Bilamana mereka sungguh belum bertobat maka merupakan suatu keganjilan untuk mendoakan mereka supaya menerima Roh Kudus. Petrus sendiri, dalam Kisah Para Rasul 2:38, menegaskan bahwa syarat untuk menerima Roh kudus: Pertama, harus bertobat; Kedua, Dibaptis dalam nama Yesus Kristus untuk pengampunan dosa. Sehingga, prinsip ini pasti diterapkan Petrus sebelum mendoakan mereka. Mereka pasti dilayani dan diberitakan Injil Yesus Kristus terlebih dahulu supaya mereka percaya kepada Kristus, sebagaimana yang nampak dalam Kisah Para Rasul 10:34-43, 19:4.

Dalam ayat 16 dikatakan: "Sebab Roh Kudus belum turun di atas seorangpun diantara mereka, karena mereka hanya dibaptis dalam Tuhan Yesus." Istilah belum, dipakai kata Yunani oudepo yang dalam bahasa Inggris not yet. Ini berbeda sekali dengan istilah ou yang berarti tidak, not. Dalam pengertian not yet terkandung sesuatu yang pasti dan akan dialami, namun belum terjadi pada saat itu. ${ }^{91}$ Istilah ini juga yang dipakai dalam Yohanes 7:39 ketika membicarakan tentang Roh Kudus yang belum datang, karena Kristus belum dimuliakan. Hal itu menunjukkan bahwa bagi orang percaya di Samaria, pengharapan untuk menerima Roh Kudus adalah suatu yang pasti akan mereka terima. Namun hal itu belum terjadi pada saat itu, nanti pada waktu kemudian. Hal itu baru terjadi pada waktu Petrus dan Yohanes mendoakan dan meletakkan tangan mereka ke atas orang Samaria. Kenyataan ini memberikan suatu petunjuk bahwa orang-orang di Samaria, kecuali Simon si Penyihir, sungguh-sungguh telah percaya kepada Kristus. ${ }^{92}$ Kelihatannya peristiwa ini agak aneh. Bagaimana mungkin orang yang telah percaya kepada Kristus tetapi tanpa Roh Kudus? Tetapi itulah kenyataan yang telah terjadi dalam jemaat di Samaria. Tentu saja ada maksud Tuhan di balik semua ini. Menurut Donald Bridge \& David Phypers:

\footnotetext{
${ }^{91}$ Bruner, A Theology Of The Holy Spirit..., 177-178.
}

92 Bnd. Abineno, Gerakan Pentakosta..., 22-23. 
Adalah cara Allah untuk menunjukkan kepada orang-orang Kristen Yahudi maupun Samaria bahwa sekarang mereka adalah anggotaanggota satu tubuh, yaitu tubuh Kristus, walaupun sampai saat itu mereka bermusuhan karena kebencian rasial dan agama yang sudah berurat berakar. Petobat-petobat baru di Samaria disadarkan bahwa mereka memerlukan jemaat induk di Yerusalem. Sebaliknya para pemimpin di Yerusalem yang merasa ragu-ragu terpaksa mengakui kenyataan daripada pertobatan orang Samaria. Sekali lagi ini benarbenar luar biasa. ${ }^{93}$

Dari pernyataan ini, nampaklah bahwa Allah bertindak demikian supaya arti dan tujuan daripada baptisan dengan Roh Kudus, yaitu untuk mempersatukan setiap orang percaya dalam jemaat sebagai tubuh Kristus, sungguh-sungguh dialami kenyataannya. Tepat apa yang dinyatakan oleh Simon Tugwell: "There is a great diversity of ways in which the Spirit works in us; the one thing that is common to all and is the bond of our unity, is baptism." 94

Semua ini membuktikan penundaan atau belum terlaksananya pemberian Roh Kudus kepada jemaat di Samaria bukan karena mereka belum bertobat. Juga bukan karena taraf iman mereka rendah sehingga membutuhkan waktu untuk meningkatkan iman mereka untuk dapat memiliki Roh Kudus atau mengalami baptisan dengan Roh Kudus. Adanya tenggang waktu dalam menerima Roh Kudus bukan karena keadaan rohani jemaat Samaria belum sesuai dengan kehendak Tuhan. Semua itu terjadi karena kehendak Allah yang bebas yang bertindak demi kebaikan jemaat Samaria itu sendiri.

Dengan demikian, nyatalah bahwa pemberian Roh Kudus atau dibaptis dengan Roh Kudus adalah semata-mata pemberian Allah yang didasarkan atas kasih dan anugerah-Nya bukan berdasarkan perbuatan atau ditentukan oleh usaha manusia sendiri. Pengalaman jemaat di Samaria dalam menerima Roh Kudus tidak dapat dijadikan pola untuk menerima Roh Kudus atau dibaptis dengan Roh bagi jemaat pada masa kini. Karena pengalaman tersebut mempunyai arti tersendiri bagi jemaat di Samaria. Seandainyapun pada masa kini "Allah benar-benar melakukan peristiwa seperti itu pada orang-orang tertentu," itu merupakan kedaulatan Allah dan bukan hasil usaha manusia, sehingga bukan suatu pola yang bersifat prinsip dan mutlak diberlakukan orang percaya.

\footnotetext{
${ }^{93}$ Bridge \& David Phypers, Karunia-karunia Roh..., 136.

${ }^{94}$ Simon Tugwell, dalam Green,. I Believe In The Holy..., 139.
} 


\section{$\underline{\text { Pengalaman Keluarga Kornelius Dalam Kisah Para Rasul } 10}$}

Bila diperhatikan peristiwa yang terjadi dalam keluarga Kornelius dan sahabat-sahabatnya, pada waktu menerima atau dibaptis dengan Roh Kudus, nampaknya tidak mengikuti urut-urutan seperti yang telah disebut oleh Petrus dalam Kisah Para Rasul 2:38. Seperti yang telah dikemukakan sebelumnya, syarat untuk dapat menerima karunia Roh Kudus atau baptisan dengan Roh Kudus, adalah bertobat (= percaya kepada Kristus) dan dibaptis dalam nama Tuhan Yesus. Tetapi kenyataannya peristiwa yang terjadi dalam keluarga Kornelius sangat berbeda. Ketika Petrus sedang memberitakan Injil dan belum membaptis mereka dalam nama Tuhan Yesus, dikatakan bahwa tiba-tiba turunlah Roh Kudus ke atas keluarga Kornelius dan sahabat-sahabatnya, yang mendengar pemberitaan Petrus. Pelayanan sakramen baptisan baru dilaksanakan setelah mereka menerima baptisan dengan Roh Kudus. Apakah ini berarti bahwa keluarga Kornelius dan sahabat-sahabatnya, jauh sebelum kedatangan Petrus ke rumahnya, memang sudah menjadi murid Tuhan Yesus sebagaimana yang dikatakan oleh gerakan Kharismatik?

Tak dapat disangkali bahwa dalam ayat 2, dikatakan bahwa keluarga ini adalah keluarga yang takut akan Allah dan banyak memberi sedekah kepada umat Yahudi dan senantiasa berdosa kepada Allah. Tapi kalau melihat penjelasan Petrus dalam pasal 11 ayat 14-18, nampaklah bahwa mereka belum termasuk murid atau orang yang sudah percaya kepada Kristus sebagai Tuhan dan Juruselamat pribadi mereka. Dikatakan dalam ayat 13-14 bahwa Tuhan menyuruh Kornelius untuk menjemput Petrus dengan tujuan agar Petrus dapat menyampaikan kepada mereka suatu berita yang akan mendatangkan keselamatan bagi Kornelius dan keluarganya serta seisi rumahnya. Kemudian dalam ayat 18 , dinyatakan bahwa Rasul-rasul dan murid-murid di Yerusalem memuliakan Allah, karena kepada bangsa-bangsa lain juga (= keluarga Kornelius dan sahabatsahabatnya) Allah mengaruniakan pertobatan yang memimpin kepada hidup. Hal ini memberikan suatu pengertian bahwa mereka belum memiliki keselamatan, sebelum Petrus memberitakan Injil kepada mereka. Mereka baru memiliki keselamatan dan Kristus sebagai Tuhan mereka, ketika Petrus memberitakan Injil kepada mereka. Pada saat itulah Allah memberikan Roh Kudus atau membaptis mereka dengan Roh Kudus. Sehingga hal itu merupakan suatu pengalaman yang pertama bukan kedua atau the second blessing.

Kesalehan dan rasa takut akan Allah dari Kornelius serta seisi rumahnya, merupakan ungkapan kesalehan dan rasa takut simpatisan 
penganut agama Yahudi. Sebab itu, mereka masih membutuhkan Injil keselamatan, yang disampaikan oleh Petrus. ${ }^{95}$

\section{Pengalaman Ke 12 Murid di Efesus Dalam Kisah Para Rasul 19:1-17}

Ada beberapa pendapat mengenai istilah murid yang dinyatakan dalam ayat-ayat tersebut. Ada yang menyatakan bahwa keduabelas murid yang ditemui oleh Paulus di Efesus adalah murid-murid dari hasil pelayanan Apollos, ketika ia belum dilayani oleh Priskila dan Akwila. ${ }^{96}$ Tetapi ada pendapat lain yang menyatakan bahwa mereka bukan muridmurid Apollos. Kemungkinan besar mereka adalah murid-murid dari pada pengikut Yohanes Pembaptis, yang tersebar keluar dari Palestina. Setelah kematian Yohanes Pembaptis, mereka menyebarluaskan baptisan dan pengajaran Yohanes Pembaptis, ${ }^{97}$ yang kemudian tiba di Efesus sesudah Apollos berangkat ke Korintus dan sebelum Paulus tiba untuk kedua kali di Efesus. Kemungkinan besar pandangan yang terakhir ini yang benar. Lepas dari segala penafsiran ini, yang perlu diperhatikan adalah bagaimana kesaksian Alkitab mengenai keadaan rohani mereka. Apakah mereka pengikut Kristus, sebelum bertemu dengan rasul Paulus atau tidak.

Dalam ayat 2-3, dinyatakan bahwa mereka menjadi murid melalui baptisan Yohanes, tetapi belum menerima Roh Kudus bahkan belum pernah mendengar akan adanya Roh Kudus. Pengertian belum menerima Roh Kudus disini berbeda dengan pengertian belum menerima Roh Kudus dalam pengalaman jemaat di Samaria. Jemaat Samaria telah percaya dan dibaptis di dalam Kristus. Mereka juga sudah mendengar dan melihat kenyataan akan adanya Roh Kudus, melalui pengajaran dan segala mujizat serta tanda ajaib yang dilakukan oleh Filipus. Sebaliknya, keduabelas murid di Efesus belum mengetahui akan adanya Roh Kudus. Itulah sebabnya menurut Anthony A. Hoekema: "It is quite obvious that these disciples were not full fledged Christian believers when Paul first met them, since they had not even heard the Holy Spirit had been given to the Church." 98

95 Bnd. F.F. Bruce, The New International Commentary on the New Testament, The Book of The Acts (Grand Rapids: Eerdmans, 1979), 216.

96 William Neil, The New Century Bible Commentary, The Acts of the Apostles (Grand Rapids: Eerdmans, 1981), 202.

97 R.C.H.Lenski, The Interpretation of the Acts of The Appostles (Minneapolis: Augsburg Publishing House, 1963), 782. 41.

98 Anthony A. Hoekema, Holy Spirit Baptism (Grand Rapids: Eerdmans, 1966), 
Jadi, kedua belas murid di Efesus belum dapat dikategorikan sebagai murid Kristus. Mereka belum memiliki keselamatan dari Kristus. Dalam ayat 4, Paulus menantang mereka untuk percaya kepada Yesus Kristus.

Selanjutnya, dalam ayat 5-6 dikatakan bahwa setelah mereka mendengar akan hal tersebut, mereka memberi diri mereka dibaptis dalam Tuhan Yesus. Dan pada waktu Paulus menumpangkan tangannya di atas mereka, Roh Kudus turun ke atas mereka dan mulailah mereka berkata-kata dalam bahasa roh dan bernubuat.

Hal itu mengidikasikan bahwa mereka menerima Roh Kudus atau dibaptis dengan Roh Kudus yaitu pada saat mereka percaya dan dibaptis dalam nama Tuhan Yesus. Pengalaman tersebut merupakan pengalaman pertama dan bukan pengalaman kedua atau the second blessing. Searah dengan hal itu, Merrill F. Unger menegaskan: "They were disciples of the Baptism, but not Christians. When they received the Holy Spirit, they became Christians. This was not a second blessing, but the first blessing, as the baptism and the reception of the Holy Spirit always is. "99

Setelah meneliti pengertian baptisan Roh Kudus atau dibaptis dengan Roh Kudus dan kesaksian Kisah Para Rasul mengenai pengalaman orang-orang percaya dalam menerima baptisan Roh Kudus, ternyata bahwa hal itu adalah merupakan suatu pengalaman semua orang percaya tanpa terkecuali. Pengalaman tersebut diterima atau terjadi pada waktu seseorang percaya kepada Yesus sebagai Tuhan dan Juruselamat pribadinya dan dibaptis di dalam nama Tuhan Yesus.

Baptisan Roh Kudus sama artinya dengan menerima Roh Kudus atau dimeteraikan dengan Roh Kudus pada waktu seseorang menerima keselamatannya. Baptisan Roh Kudus berkenan dengan pengalaman pertama kali seseorang percaya dan terjadi secara bersamaan dengan kelahiran baru dan pertobatan dan sebab itu tidak mungkin terjadi kembali.

Dalam kesaksian Kisah Para Rasul, ada pengalaman dari beberapa orang percaya yang menerima baptisan Roh Kudus setelah percaya kepada Kristus dan melewati satu masa tertentu. Hal tersebut merupakan suatu kejadian yang khusus, sehingga bukan merupakan suatu pola dan prinsip dalam menerima baptisan Roh Kudus.

Berkaitan dengan relasi baptisan Roh Kudus dan karunia-karunia Roh, menurut kesaksian Kisah Para Rasul, karunia-karunia Roh (mis. karunia bernubuat dan berkata-kata dengan bahasa Roh) diterima pada

${ }^{99}$ Merrill F. Unger, The Baptizing work of the Holy Spirit (Chocago: Scripture Press Fondation, 1953), 73. 
waktu seseorang menerima atau dibaptis dengan Roh Kudus. Selanjutnya, menurut pengajaran Paulus, yaitu dalam Roma 12:6; 1Korintus 1:7, 12:7,11; Efesus 4:7 dikatakan bahwa Allah telah memberikan karuniakarunia Roh kepada semua orang percaya atau jemaat, sesuai dengan kehendak-Nya. Itu berarti bahwa setiap orang percaya, tanpa terkecuali, telah menerima karunia-karunia Roh, paling sedikit satu karunia Roh. Hal tersebut diterima pada saat seseorang menerima Roh Kudus atau dibaptis dengan Roh Kudus, yaitu pada saat ia percaya kepada Kristus dan dibaptis di dalam nama Tuhan Yesus. Dengan kata lain, pada saat seseorang percaya kepada Kristus sebagai Tuhan dan Juruselamat pribadinya dan dibaptis di dalam nama Tuhan Yesus, saat itulah ia menerima keselamatan, menjadi anggota tubuh Kristus, menerima Roh Kudus dan karunia-karunia Roh.

Apa yang diajarkan oleh beberapa tokoh, theolog dari NeoPentakosta tentang baptisan dengan Roh Kudus dan relasinya dengan karunia-karunia Roh, jelas tidak sesuai dengan kesaksian Alkitab. Alkitab tidak pernah mengajarkan bahwa hanya orang-orang percaya tertentu saja yang menerima baptisan Roh Kudus dan karunia-karunia Roh. Jurstru sebaliknya Alkitab mengajarkan bahwa semua orang percaya, tanpa memandang kualitas kerohaniannya, telah menerima baptisan Roh Kudus dan karunia-karunia Roh. Misalnya, jemaat Korintus, jemaat yang penuh dengan bermacam-macam dosa dan kesalahan, dikatakan oleh Paulus telah menerima baptisan Roh Kudus dan karunia-karunia Roh, sesuai dengan kehendak Allah. Hal ini kurang diperhatikan oleh gerakan Kharismatik.

Memang di satu segi, walaupun pengajaran tersebut mengenal hal tersebut di atas tidak dapat dipertanggungjawabkan kebenarannya, namun usaha mereka untuk melayani dan menyaksikan Kristus berdasarkan kuasa Allah dan karunia-karunia Roh, perlu kita hargai. Sekaligus merupakan suatu kritik yang positif terhadap Gereja-gereja di Indonesia (khususnya Gereja-gereja yang bersifat tradisionil) yang kebanyakan kurang memperhatikan dan mengajarkan akan manfaat karunia-karunia Roh yang ada pada setiap anggota jemaat bagi pelayanan jemaat. Sehingga hal itu berakibat kepada kehidupan berjemaat, dimana banyak anggota jemaat menjadi statis, pasif dan acuh tak acuh terhadap pelayanan jemaat. Bahkan tidak jarang keadaan ini mendorong sebagian anggota jemaat untuk terbuka pada pengajaran yang baru yang ditawarkan oleh Neo-Pentakosta dan kemudian menjadi pengikutnya. Hal ini harus disadari oleh Gereja-gereja di Indonesia. Demikian juga, tidak ada artinya mengetahui bahwa setiap orang percaya telah mengalami baptisan Roh Kudus dan memiliki karuniakarunia Roh, kalau jemaat itu sendiri tidak terlibat atau dilibatkan dalam pelayanan jemaat dan mengalami kelimpahan karunia Roh Kudus. 


\section{Karunia-karunia Roh dan Kualitasnya}

Berkaitan dengan pandangan gerakan Neo-Pentakosta Kharismatik, yang sangat mengutamakan karunia-karunia Spektakular, secara khusus bahasa roh; bahkan menganggap karunia-karunia Roh terbatas pada kesembilan karunia Roh dalam 1Korintus 12:8-10, hal itu tidak dapat dibenarkan. Hal itu bertentangan dengan pengajaran rasul Paulus sendiri.

Rasul Paulus ketika membicarakan karunia-karunia Roh Kudus, tidak pernah membeda-bedakan dan menganggap bahwa satu atau beberapa karunia Roh Kudus tertentu lebih bernilai dan lebih berkualitas daripada karunia-karunia yang lain. Khusus mengenai kesembilan karunia Roh yang dicantumkan dalam 1Korintus 12:8-10, Paulus tidak pernah menyatakan bahwa hanya karunia-karunia tersebutlah yang dikategorikan sebagai karunia Roh Kudus dan yang lain bukan karunia Roh Kudus. Hal itu nampak dalam istilah yang dipergunakan oleh rasul Paulus untuk karuniakarunia Roh Kudus. Sebagaimana yang telah diuraikan sebelumnya, bahwa istilah yang dipergunakan oleh rasul Paulus untuk segala karunia Roh Kudus adalah charismata. Istilah charismata yang digunakan dalam 1Korintus 12:4 untuk kesembilan karunia yang bersifat supra-natural dan yang dalam 1Korintus 12:9,28,30, yang dipergunakan untuk salah satu karunia spectacular (karunia penyembuhan); dipergunakan juga oleh Paulus dalam Roma 12:6 untuk karunia bernubuat, karunia melayani, karunia mengajar, karunia menasehati, karunia memimpin, karunia membagibagikan sesuatu dan karunia kemurahan. Hal itu menunjukkan bahwa bagi Paulus karunia-karunia Roh, charismata, tidak hanya terbatas pada kesembilan karunia Roh Kudus yang disebutkan dalam 1Korintus 12:8-10 atau hanya pada karunia spectacular, melainkan untuk semua karunia Roh yang telah disebutkan oleh Paulus.

When one studies the use of the word charismata in the New Testament, moreover, it becomes quite evident that one cannot limit the meaning of this word to spectacular or miraculous gifts like healing or tongue speaking. Charismata in the New Testament designated whatever gifts the Holy Spirit wishes to use for the upbuilding of the church. ${ }^{100}$

Bagi rasul Paulus seluruh karunia Roh Kudus, mempunyai nilai dan kualitas yang sama. Diantara karunia-karunia Roh Kudus, tidak ada yang lebih tinggi atau lebih rendah kualitasnya. Tidak ada karunia Roh Kudus yang lebih istimewa atau lebih penting daripada karunia yang lain.

${ }^{100}$ Hoekema, Holy Spirit..., 57. 
Karunia-karunia Roh Kudus yang bersifat supra-natural tidak lebih tinggi atau lebih istimewa daripada karunia-karunia Roh Kudus yang bersifat natural. Semuanya istimewa, bernilai dan berkualitas. Karena semua berasal dari Allah yang satu dan diberikan untuk pelayanan dan pembangunan jemaat. Dengan demikian, semua karunia Roh Kudus sama pentingnya. Searah dengan hal itu, Abineno menegaskan: "Pendapat yang mengatakan, bahwa kharisma-kharisma yang spektakular... lebih penting daripada kharisma-kharisma yang lain. Pendapat ini-sama seperti pendapat-pendapat di atas-tidak benar. Ia bertentangan dengan kesaksian Kitab Suci."101

Untuk lebih memahami akan hal tersebut, perlu dilihat apa yang dikemukakan Paulus dalam surat-suratnya. Dalam Roma 12:6-8, rasul Paulus mencantumkan dan menggabungkan bersama-sama karunia Roh Kudus yang bersifat supra-natural (karunia bernubuat) dengan karuniakarunia Roh Kudus yang lain yang bersifat natural (melayani, mengajar, menasehati, membagi-bagikan sesuatu, memberi pimpinan dan kemurahan). Hal yang sama dinyatakan dalam 1Korintus 12:28, karunia-karunia Roh Kudus yang bersifat natural (karunia memimpin dan melayani) digabung bersama-sama dengan karunia-karunia Roh Kudus yang bersifat supranatural atau yang bersifat spectacular (mujizat, menyembuhkan dan berkata-kata dalam bahasa roh. Semuanya ini menunjukkan akan adanya kesejajaran antara semua karunia Roh Kudus, antara yang bersifat spektakular dan yang bersifat natural.

Dalam 1Korintus 12:12-26, rasul Paulus memang menjelaskan bahwa sebagaimana tubuh manusia terdiri dari bermacam-macam anggota tubuh, demikian juga jemaat, sebagai tubuh Kristus. Tiap-tiap anggota jemaat berbeda satu sama yang lain, sesuai dengan karunianya. Dengan kata lain, Paulus memang menyadari bahwa antara satu karunia Roh Kudus dengan karunia Roh Kudus yang lain, ada perbedaannya. Karunia bernubuat berbeda dengan karunia kemurahan. Karunia untuk berkata-kata dengan bahasa roh berbeda dengan karunia mengajar. Karunia penyembuhan berbeda dengan karunia untuk menasehati. Namun demikian, sekali lagi, perbedaan tersebut bukan dalam soal kualitasnya, melainkan dalam soal fungsinya. Fungsi kaki berbeda dengan fungsi mata. Fungsi mata berbeda dengan fungsi telinga. Kaki untuk berjalan, mata untuk melihat dan telinga untuk mendengar. Demikian juga dengan karunia-karunia. Perbedaan tersebut, bagi rasul Paulus, bukan untuk dipertentangkan ataupun untuk dibanggakan dan diperbandingkan antara satu karunia dengan karunia Roh

101 Abineno, Karunia-Karunia Roh..., 13. 
Kudus yang lain. Melainkan untuk saling memperlengkapi dan oleh karena itu saling membutuhkan.

Dalam ayat 22-24, rasul Paulus menjelaskan bahwa anggotaanggota tubuh yang kelihatan paling lemah, justru paling dibutuhkan. Anggota-anggota tubuh yang menurut pandangan manusia kurang terhormat, justru diberi penghormatan secara khusus. Anggota-anggota tubuh yang kelihatan tidak elok, justru diberikan perhatian secara khusus.

Dalam hal ini, rasul Paulus ingin menunjukkan bahwa tidak ada satu karunia Roh Kudus yang dapat dianggap kurang dibutuhkan, kurang terhormat dan kurang mulia. Dengan kata lain tidak ada karunia Roh Kudus yang dapat dianggap paling dibutuhkan, paling terhormat dan paling mulia daripada karunia-karunia Roh Kudus yang lain. Melainkan, semua karunia Roh Kudus sangat dibutuhkan, semuanya terhormat dan semuanya mulia. Karena semuanya adalah pemberian daripada Allah. Dan semua yang datangnya daripada Allah pasti bermanfaat bagi kehidupan jemaat, terhormat dan mulia. Selanjutnya mengenai karunia untuk berkata-kata dengan bahasa roh. Rasul Paulus tidak pernah menyatakan bahwa karunia tersebut paling penting dan mutlak harus dimiliki oleh setiap orang percaya. Demikian juga, karunia tersebut bukan merupakan suatu bukti atau tanda satu-satunya menerima baptisan dengan Roh Kudus. Hal ini nampak dalam uraian di bawah ini.

Dalam 1Korintus 12:8-10, rasul Paulus menyatakan bahwa setiap orang percaya menerima karunia Roh Kudus berbeda satu dengan yang lain. Ada yang menerima karunia untuk berkata-kata dengan hikmat, ada yang menerima karunia untuk berkata-kata dengan pengetahuan, ada yang menerima karunia bernubuat, ada yang menerima karunia iman, ada yang menerima karunia untuk berkata-kata dengan bahasa roh, dan seterusnya.

Dalam 1Korintus 12:28-30, Paulus kembali menyatakan bahwa ada yang ditetapkan Allah untuk menjadi rasul, nabi dan pengajar. Ada pula yang menerima karunia mengadakan mujizat, menyembuhkan, melayani, memimpin, dan untuk berkata-kata dengan bahasa Roh. Dalam ayat 29-30, Paulus menyatakan: Apakah mereka semua rasul, nabi, pengajar? Adakah mereka semua mendapat karunia untuk mengadakan mujizat atau menyembuhkan atau untuk berkata-kata dalam bahasa roh, atau untuk menafsirkan bahasa roh? Jawabannya adalah tidak. Kemudian dalam 1Korintus 12:11, rasul Paulus menyatakan bahwa semua karunia-karunia Roh diberikan kepada setiap orang percaya, sesuai dengan kehendak Allah.

Hal tersebut menunjukkan bahwa tidak semua orang percaya harus senantiasa menerima karunia Roh Kudus yang sama. Demikian juga tidak semua orang percaya harus menerima karunia mujizat, menyembuhkan dan 
untuk berkata-kata dengan bahasa roh. Karena yang menentukan pemberian karunia-karunia Roh Kudus adalah Allah sendiri dan bukan manusia.

Dalam 1Korintus 14:1-25, rasul Paulus menjelaskan bahwa karunia untuk berkata-kata dengan bahasa roh, hanya bermanfaat bagi mereka yang memilikinya. Namun kalau ada yang menafsirkannya maka karunia tersebut dapat bermanfaat bagi jemaat. Kemudian dalam ayat 5, rasul Paulus menjelaskan bahwa karunia bernubuat sangat bermanfaat bagi jemaat, bilamana dibandingkan dengan karunia untuk berkata-kata dengan bahasa roh. Alasannya, menurut Paulus dalam ayat 3,24-25, orang yang bernubuat langsung berkata-kata kepada manusia; ia membangun, menasehati dan menghibur jemaat. Demikian juga, karunia bernubuat dapat membawa orang yang tidak beriman untuk sujud menyembah Allah dan mengakui akan kehadiran Allah dalam jemaat, ketika mendengar perkataan yang disampaikan melalui karunia bernubuat. Paulus tidak pernah mengistimewakan karunia untuk berkata-kata dengan bahasa Roh. Sebaliknya juga, Paulus tidak mempunyai tujuan untuk membandingbandingkan antara satu karunia dengan karunia yang lain. Juga bukan untuk menyatakan karunia nubuat lebih istimewa dan penting daripada karunia untuk berkata-kata dengan bahasa roh. Paulus ingin menyatakan bahwa betapa pentingnya karunia-karunia Roh Kudus dipergunakan bagi pembangunan jemaat. Karena itulah tujuan Allah memberikan karuniakarunia Roh Kudus kepada jemaat.

Melalui semua pembahasan tersebut di atas, dapat disimpulkan bahwa ternyata karunia-karunia Roh Kudus tidak hanya terbatas pada Sembilan karunia Roh, sebagaimana yang dikatakan oleh Neo-Pentakosta atau Kharismatik. Ia mencakupi semua karunia Spektakular dan non spektakular seperti yang telah Paulus sebutkan dalam Roma 12:6-8; Efesus 4:11, 1Korintus 7:7, 12:8-10, 28-30. Demikian juga, karunia untuk berkatakata dengan bahasa roh bukan merupakan suatu kemutlakan untuk dimiliki sebagai bukti telah dibaptis dengan Roh Kudus. Allah memberikan karunia Roh kudus sesuai kehendak-Nya.

Dari antara semua karunia Roh Kudus tersebut, tidak ada karunia Roh Kudus tertentu yang lebih penting atau lebih tinggi kualitasnya daripada karunia-karunia Roh Kudus yang lain. Semua karunia Roh Kudus sama penting sama kualitasnya. Karena, semua karunia Roh Kudus berasal dari pada Allah dan diberikan untuk pelayanan dan pembangunan jemaat, sebagai tubuh Kristus. 


\section{PENUTUP: KESIMPULAN}

Menurut Rasul Paulus, yang dimaksud dengan karunia Roh adalah suatu kesanggupan khusus yang diberikan Allah kepada setiap orang percaya sesuai kehendak-Nya guna dipakai bagi kepentingan jemaat sebagai tubuh Kristus. Pemberian ini dimungkinkan karena karya keselamatan Kristus di atas kayu salib. Dasar pemberian karunia Roh adalah semata-mata karena kasih dan anugerah Allah, bukan hasil usaha manusia atau sebagai suatu pahala atas jasa manusia.

Karunia Roh berbeda dengan talenta. Karunia Roh diberikan Allah kepada orang percaya untuk kemuliaan Allah. Talenta adalah bakat atau kesanggupan khusus pembawaan seseorang sejak lahir, digunakan untuk kepentingan umum manusia. Setiap talenta/bakat dapat dipakai dan diubahNya sebagai karunia Roh pada saat orang tersebut percaya kepada-Nya.

Berdasarkan pengertian bahwa karunia-karunia Roh diberikan Allah kepada jemaat untuk pelayanan dan pembangunan tubuh Kristus, maka setiap anggota jemaat atau orang percaya mempunyai tanggung jawab di dalam pelayanan jemaat. Tanggungjawab itu tidak dapat diwakilkan dan dimonopoli orang lain, secara khusus oleh para pelayan jemaat. Para pelayan jemaat bertanggung jawab untuk memperlengkapi dan mempersiapkan setiap anggota jemaat bagi pelayanan dan pembangunan jemaat, sebagai tubuh Kristus.

Jemaat dengan segala karunianya merupakan potensi yang amat besar bagi perkembangan dan pertumbuhan tubuh Kristus. Melalaikan potensi ini berarti kehilangan kesempatan bahkan dapat menghalangi pertumbuhan jemaat. Sebaliknya, melibatkan setiap anggota jemaat, sesuai dengan karunianya, dalam Pelayanan Kesaksian (Marturia), Pelayanan Persekutuan (Koinonia), Pelayanan Sosial (Diakonia) akan berakibat pada pertumbuhan jemaat secara kualitatif dan kuantitatif. Karena itulah tujuan Allah memberikan karunia-karunia Roh kepada jemaat-Nya.

Karunia-karunia Roh yang diberikan Allah kepada setiap orang percaya beranekaragam dan berbeda-beda. Perbedaan ini bukan untuk dipertentangkan atau diistimewakan melainkan untuk saling melengkapi satu dengan yang lain, agar seluruh orang percaya sampai kepada kesempurnaan Kristus. Setiap karunia tidak lebih penting dan istimewa daripada karunia-karunia yang lain. Semua sama penting dan sama kualitasnya karena bersumber dari Allah yang sama.

Pandangan yang menganggap karunia-karunia Roh yang bersifat spektakular lebih penting daripada karunia-karunia Roh yang lain, tidak benar. Demikian juga, memutlakkan karunia berkata-kata dengan bahasa 
roh bagi setiap orang percaya tidak sesuai dengan kebenaran Firman Tuhan. Setiap orang percaya menerima karunia yang berbeda-beda, sesuai dengan kehendak Allah.

Karunia-karunia Roh diberikan Allah kepada setiap orang percaya, pada saat percaya kepada Kristus dan dibaptis di dalam nama-Nya. Pengalaman orang percaya menerima karunia-karunia Roh berlangsung secara simultan. Saat seseorang percaya kepada Kristus dan dibaptis dalam nama-Nya, pada saat itu secara simultan ia menerima keselamatan, menjadi anggota tubuh Kristus, menerima Roh Kudus dan karunia-karunia Roh. Dan menurut Paulus, inilah yang dimaksud dengan dibaptis dengan Roh Kudus.

Oleh karena itu, pandangan yang menyatakan pengalaman tersebut berbeda, tidak simultan dengan kelahiran baru melainkan merupakan pengalaman kedua atau second blessing dan karena itu hanya merupakan pengalaman beberapa orang percaya tertentu saja adalah tidak benar. 